\title{
Primary Sensory Neuron Addition in the Adult Rat Trigeminal Ganglion: Evidence for Neural Crest Glio- Neuronal Precursor Maturation
}

\author{
Alfonso Lagares, ${ }^{1,2 \star}$ Hong-Yun Li, ${ }^{3 \star}$ Xin-Fu Zhou, ${ }^{3}$ and Carlos Avendaño ${ }^{1}$ \\ ${ }^{1}$ Department of Anatomy, Histology, and Neuroscience, Autonoma University of Madrid, Medical School, 28029 Madrid, Spain, ${ }^{2}$ Department of \\ Neurosurgery, Hospital 12 de Octubre, 28041 Madrid, Spain, and ${ }^{3}$ Department of Human Physiology, Centre for Neuroscience, Flinders University, \\ Adelaide 5001, South Australia, Australia
}

It is debated whether primary sensory neurons of the dorsal root ganglia increase the number in adult animals and, if so, whether the increase is attributable to postnatal neurogenesis or maturation of dormant, postmitotic precursors. Similar studies are lacking in the trigeminal ganglion (TG). Here we demonstrate by stereological methods that the number of neurons in the TG of adult male rats nearly doubles between the third and eighth months of age. The increase is mainly attributable to the addition of small, B-type neurons, with a smaller contribution of large, A-neurons. We looked for possible proliferative or maturation mechanisms that could explain this dramatic postnatal expansion in neuron number, using bromodeoxyuridine (BrdU) labeling, immunocytochemistry for neural precursor cell antigens, retrograde tracing identification of peripherally projecting neurons, and in vitro isolation of precursor cells from adult TG explant cultures. Cell proliferation identified months after an extended BrdU administration was sparse and essentially corresponded to glial cells. No BrdU-labeled cell took up the peripherally injected tracer, and only a negligible number coexpressed BrdU and the pan-neuronal tracer neuron-specific enolase. In contrast, a population of cells not recognizable as mature neurons in the TG and neighboring nerve expressed neuronal precursor antigens, and neural crest glioneuronal precursor cells were successfully isolated from adult TG explants. Our data suggest that a protracted maturation process persists in the TG that can be responsible for the neuronal addition found in the adult rat.

Key words: primary sensory neurons; gasserian ganglion; stereology; axotomy; precursor cells; postnatal neurogenesis

\section{Introduction}

The increase in the number of cells in sensory ganglia of adult animals has been a matter of controversy since it was reported (Devor and Govrin-Lippmann, 1985, 1991; Coggeshall, 1991; La Forte et al., 1991). Neural counting methods were considered responsible for these conflicting results; however, the situation was not entirely clarified by the use of stereological methods, because results from groups using these methods also differed (Cecchini et al., 1995; Popken and Farel, 1997; Ciaroni et al., 2000; Mohammed and Santer, 2001). The origin of the possible

Received March 17, 2007; revised May 25, 2007; accepted June 8, 2007.

This project was supported by Spain's Ministry of Education Project Grant BFU2004 - 05233-BFI (A.L., C.A.) and National Health and Medical Research Council Grants 375109 and 375110 (X.-F.Z.). Some monoclonal antibodies were obtained from the Developmental Studies Hybridoma Bank (University of lowa, lowa City, IA) under the auspices of National Institute of Child Health and Human Development and maintained by The University of lowa. We are grateful to Prof. M. V. Chao (New York University, New York, NY) and Dr. M.-L. Rogers (Flinders University, Adelaide, Australia) for p75NTR antibodies, Dr. Mark Marchionni (Cambridge NeuroScience, Cambridge, MA) for recombinant human glial growth factor 2 protein, and Jinxian Mi and Rosa Sanchez for technical assistance.

${ }^{*}$ A.L. and H.-Y.L. contributed equally to this work.

Correspondence should be addressed to either of the following: Carlos Avendaño, Department of Anatomy, Histology, and Neuroscience, Autonoma University of Madrid, Medical School, 28029 Madrid, Spain, E-mail: carlos.avendano@uam.es; or Xin-Fu Zhou, Department of Human Physiology, Flinders University, G.P.0. Box 2100, Adelaide 5001, South Australia, Australia, E-mail: xin-fu.zhou@flinders.edu.au.

D0I:10.1523/JNEUROSCI.1203-07.2007

Copyright $\odot 2007$ Society for Neuroscience $\quad$ 0270-6474/07/277939-15\$15.00/0 increase in sensory neurons is also in dispute. Although some authors have pointed out the possible existence of neurogenesis in adult dorsal root ganglia (DRGs) (Devor and GovrinLippmann, 1985; Devor et al., 1985; Cecchini et al., 1995), others have suggested that these new neurons could instead derive from the maturation or growth of preexisting immature cells (Farel, 2003).

No similar studies have been performed on the trigeminal ganglion (TG), despite the major attention that the trigeminal system receives, particularly in rodents. This ganglion contains the bodies of the first neurons in somatosensory pathways arising from receptors and free nerve endings in the facial and oral tissues and part of the dura mater and is formed by a variety of neuron types, which are similar to those present in DRGs. The experimental manipulation or pathological conditions of the peripheral nerves or receptors result in phenotypic changes of DRG or TG neurons (Hökfelt et al., 1994; Cherkas et al., 2004), which are of primary interest to understand the functional and structural reorganizations occurring at higher levels of the system. A consensus exists that target removal or irreversible damage to a peripheral sensory nerve brings about neuronal loss in the DRGs. However, reported quantitative data show large variability, consistent with the multifactorial dependence of neurons for survival after axotomy, such as animal age, nerve type, distance of tran- 
section from the soma, availability of trophic factors, and postlesion survival time (Ljungberg et al., 1999; McKay et al., 2002; Kuo et al., 2005; Zhou et al., 2005). A major and often neglected additional factor is the method used for quantitation (Tandrup et al., 2000), as well as the normal occurrence of side differences in neuron number in the DRG (Ygge et al., 1981; Avendaño and Lagares, 1996). All of these sources of variability must be considered to quantitatively assess the effects of different experimental conditions on sensory neurons.

This study was aimed to test in the adult rat (1) whether the normal TG displays differences in neuron numbers regarding side or age, (2) the effect of chronic peripheral deafferentation on neuron numbers, (3) whether proliferative mechanisms remain in TG beyond the third postnatal month, and (4) whether postmitotic but immature neurons or neuronal precursors are present in the ganglion. Furthermore, to better explain cell number changes in the adult TG, we isolated and characterized possible precursor cells in vitro.

\section{Materials and Methods}

\section{Quantitative studies in adult rat TG in vivo}

Animals, surgery, and histology. Animals used for quantitative studies were 22 male adult Sprague Dawley rats from different dams. Their groups, weights, and ages are shown in Table 1. Deafferentation was performed in the right side on seven rats at 3 months of age. Under pentobarbital anesthesia $(35 \mathrm{mg} / \mathrm{kg}$, i.p.), the infraorbital nerve (ION) was exposed at its exit from the infraorbital foramen. The nerve was transected and the stumps were tightly ligated to prevent regeneration.

Table 1. Body weight, neuronal number, neuronal volume and ganglion volume per side [mean (SD)]

\begin{tabular}{lccllll}
\hline & $n$ & Weight $(\mathrm{g})$ & Side & $\begin{array}{l}\text { Neuron number } \\
\text { (in thousands) }\end{array}$ & $\begin{array}{l}v_{N} \text { (in thousand } \\
\left.\mu \mathrm{m}^{3}\right)\end{array}$ & $\begin{array}{l}\text { Ganglion volume } \\
\left(\mathrm{mm}^{3}\right)\end{array}$ \\
\hline & & & & & & \\
Control 3 months & 9 & $315(60)$ & $\mathrm{L}$ & $34.9(5.3)$ & $7.3(1.4)$ & $1.25(0.20)$ \\
& & & $\mathrm{R}$ & $35.6(5.8)$ & $8.6(1.1)^{* *}$ & $1.25(0.21)$ \\
Control 8 months & 6 & $553(96)$ & $\mathrm{L}$ & $61.9(6.5)^{*}$ & $7.2(0.1)$ & $2.13(0.19)^{*}$ \\
& & & $\mathrm{R}$ & $61.8(7.4)^{*}$ & $8.4(0.7)^{* *}$ & $2.05(0.35)^{*}$ \\
Deafferented 7 months & 7 & $548(68)$ & $\mathrm{L}$ & $56.5(5.2)^{*}$ & $9.8(2.4)$ & \\
& & & $\mathrm{R}$ & $45.5(8.2)^{* *}$ & $9.7(2.5)$ & \\
\hline
\end{tabular}

L, Left; $R$, right. ${ }^{*} p<0.05$, different from 3-month-old group; ${ }^{* *} p<0.05$, different from contralateral side.
The animals were allowed to recover and survived 4 months in standard laboratory cages. At the established age, the rats were deeply anesthetized (70 mg pentobarbital, i.p.) and perfused through the ascending aorta with $0.9 \% \mathrm{NaCl}(1 \mathrm{~min})$, followed by $4 \%$ paraformaldehyde in $0.1 \mathrm{M}$ phosphate buffer $(\mathrm{PB})$. All procedures were approved by the Ethical Committee of the Autonoma University of Madrid, in accordance with Council Directive 86/609/EEC of the European Community. Every effort was made to minimize the suffering of the animals and the number of animals used.

Both TGs were exposed and excised by cutting the trigeminal root at its entrance in the brainstem, the mandibular branch $5 \mathrm{~mm}$ distally to the ganglion, and the maxillary branch at the level of the orbital fissure. After $1 \mathrm{~d}$ fixation in the same fixative, each ganglion was individually dehydrated in ethanol and defatted in ether. To guarantee isotropy along the longitudinal axis of the ganglion, each ganglion was cut into two parts of similar size along its longitudinal axis (Tandrup, 1993), and both parts were sequentially infiltrated in ascending concentrations of low viscosity nitrocellulose (Celloidin; Fluka, Buchs, Switzerland) dissolved in a 1:1 mixture of ethanol/ether. Before the final embedding step, each piece was randomly rotated along its longitudinal axis. In two animals, their ganglia were not cut but were included in one piece in the celloidin block to check whether the division of the ganglion in two halves had any influence in the quantification. Celloidin blocks were cut on a sliding microtome at $50 \mu \mathrm{m}$, all sections were Nissl stained with $0.5 \%$ cresyl violet, and every fourth section was used for counting. These embedding and sectioning procedures were used to obtain "vertical" sections using the longitudinal axis of the ganglia as the vertical axis (Lagares and Avendaño, 2000). All measurements were performed with the investigator not knowing which side or case was being studied.

Neurons were classified into the two basic types already described (Andres, 1961; Lagares and Avendaño, 2000): A-type cells are large and contain small- to medium-sized clumps of Nissl substance that are more abundant in the central portions of the cytoplasm and are sparser in the periphery. They display a prominent and heavily stained nucleolus centrally located within a large and lightly stained nucleus. B-type cells are small to medium sized and contain coarser clumps of Nissl substance more widely distributed in the cytoplasm. In some cases, these clumps tend to concentrate at the

Table 2. Antibodies used, source, and dilution

\begin{tabular}{|c|c|c|c|c|c|}
\hline Antigen (clone) & Type & Species & Clonality & Dilution & Source \\
\hline Nestin (RAT401) & $\lg G 1$ & Mouse & Monoclonal & $1: 1000$ & $\begin{array}{l}\text { Developmental Studies Hybridoma Bank, University } \\
\text { of lowa, lowa City, IA }\end{array}$ \\
\hline Islet $1 / 2$ & $\lg G$ & Mouse & Monoclonal & $1: 200$ & \\
\hline BrdU (G3G4) & $\lg G 1$ & Mouse & Monoclonal & $1: 5000$ & \\
\hline NF200 (N52) & $\lg G 1$ & Mouse & Monoclonal & $1: 1000$ & Sigma \\
\hline$\beta$ III-Tubulin (SDL0.3D10) & $\lg G 2 b$ & Mouse & Monoclonal & $1: 500$ & \\
\hline GFAP (G-A-5) & $\lg G 1$ & Mouse & Monoclonal & $1: 500$ & \\
\hline SMA (1A4) & $\lg G 2 a$ & Mouse & Monoclonal & $1: 500$ & \\
\hline BrdU (Bu20a) & $\lg G$ & Mouse & Monoclonal & $1: 200$ & DakoCytomation \\
\hline GFAP & $\lg G$ & Rabbit & Polyclonal & $1: 1000$ & \\
\hline$S 100 \beta$ & $\lg G$ & Rabbit & Polyclonal & $1: 1000$ & \\
\hline \multirow[t]{2}{*}{ DCX } & $\lg G$ & Rabbit & Polyclonal & $1: 1000$ & Abcam, Cambridge, MA \\
\hline & & Goat & & $1: 100$ & Santa Cruz Biotechnology, Santa Cruz, CA \\
\hline PGP9.5 & $\lg G$ & Rabbit & Polyclonal & $1: 1000$ & Chemicon \\
\hline p75NTR (MC192) & $\lg G 1$ & Mouse & Monoclonal & $1: 1000$ & \\
\hline p75NTR $(\# 9650)^{a}$ & $\lg G$ & Rabbit & Polyclonal & $1: 2000$ & $\begin{array}{l}\text { Gift from Prof. M. V. Chao, New York University, New } \\
\text { York, NY }\end{array}$ \\
\hline P75NTR $(M L R 3)^{b}$ & $\lg G 2 a$ & Mouse & Monoclonal & $1: 500$ & $\begin{array}{l}\text { Gift from Dr. M.-L. Rogers, Flinders University, Ad- } \\
\text { elaide, South Australia, Australia }\end{array}$ \\
\hline NSE & $\lg G$ & Rabbit & Polyclonal & $1: 2000$ & Polysciences, Warrington, PA \\
\hline
\end{tabular}

${ }^{a}$ Characterized by Dr. Chao's Laboratory (Huber and Chao, 1995).

${ }^{b}$ Characterized previously by Rogers et al. (2006). 
Table 3. Primers and PCR conditions for respective genes

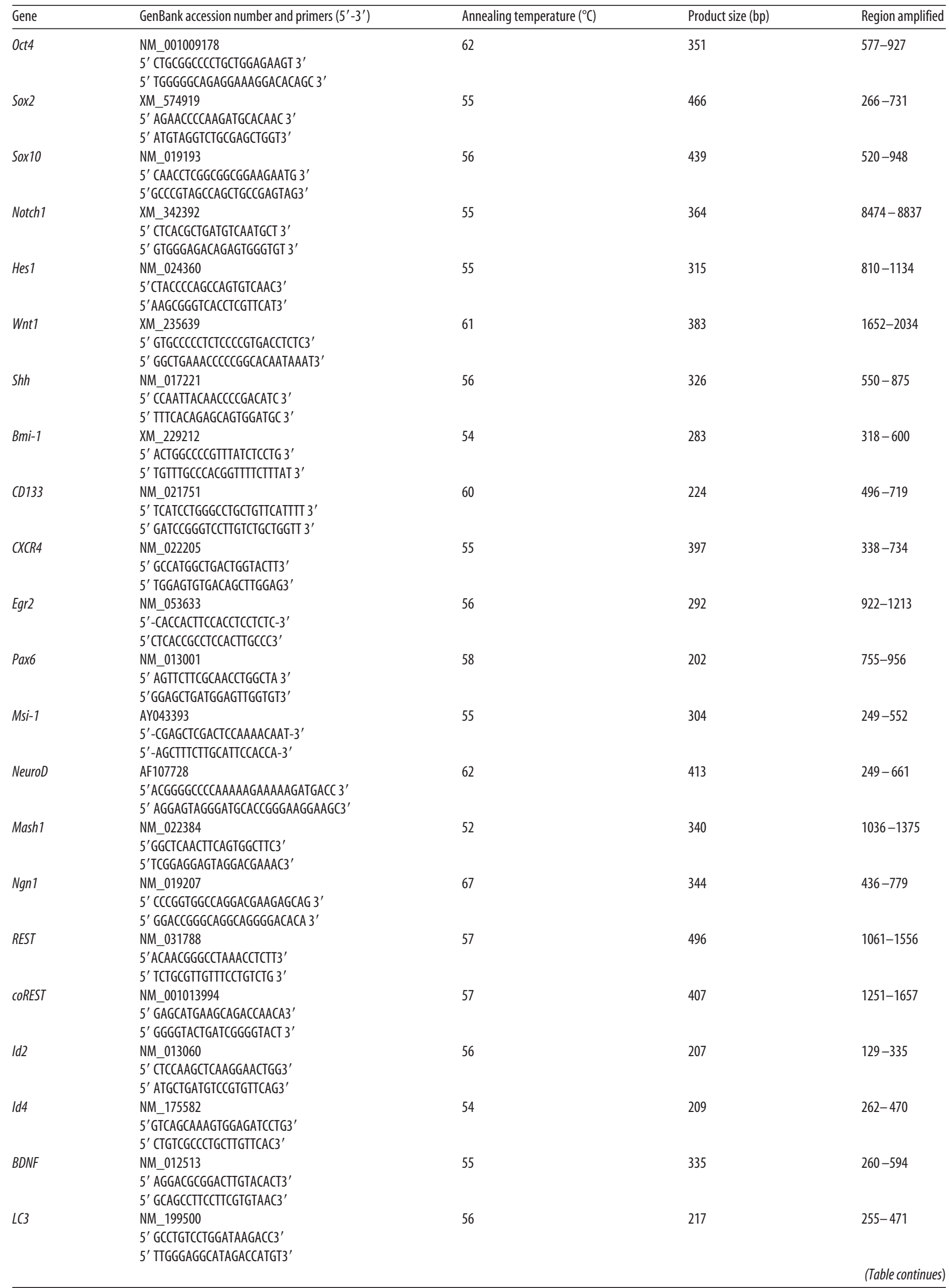


Table 3. Continued

\begin{tabular}{|c|c|c|c|c|}
\hline Gene & GenBank accession number and primers $\left(5^{\prime}-3^{\prime}\right)$ & Annealing temperature $\left({ }^{\circ} \mathrm{C}\right)$ & Product size (bp) & Region amplified \\
\hline Beclin1 & $\begin{array}{l}\text { AY033824 } \\
\text { 5' GTGCTCCTGTGGAATGGAAT3' } \\
\text { 5' CCACTTGAGATTCGTCAGCA 3' }\end{array}$ & 56 & 431 & $878-1308$ \\
\hline Snail1 & $\begin{array}{l}\text { NM_053805 } \\
\text { 5' GAGGACAGTGGCAAAAGCTC3' } \\
\text { 5' AGGACATTCGGGAGAAGGTT 3' }\end{array}$ & 54 & 469 & $360-808$ \\
\hline Twist1 & $\begin{array}{l}\text { NM_053530 } \\
\text { 5' ACGACAGCCTGAGCAACAG 3' } \\
\text { 5' GCAGGACCTGGTACAGGAAG 3' }\end{array}$ & 55 & 453 & $219-672$ \\
\hline FoxD3 & $\begin{array}{l}\text { XM_001061117 } \\
\text { 5'ACGACGGGCTGGAGGAGA3' } \\
\text { 5'GGCTTGTTCGGGGTCAGA 3' }\end{array}$ & 54 & 280 & $95-374$ \\
\hline Brn3a & $\begin{array}{l}\text { XM_001076964 } \\
\text { 5'GGTGTCCCAGGGCAAGAG3' } \\
\text { 5'CGACGGCGACGAGATGTG3' }\end{array}$ & 55 & 173 & $200-371$ \\
\hline G3PDH & $\begin{array}{l}\text { X02231 } \\
5^{\prime} \text {-ACCACAGTCCATGCCATCAC-3' } \\
\text { 5'-TCCACCACCCTGTTGCTGTA-3' }\end{array}$ & 55 & 452 & $591-1042$ \\
\hline
\end{tabular}

periphery of the perikaryon or form a ring around the nucleus. Approximately $5 \%$ of the TG neurons contain two nucleoli. Uncertain neuron types $(<5 \%)$ were classified as B.

Stereology. The absolute number of neurons $(N)$ and the mean neuronal volume $\left(v_{N}\right)$ and distribution of individual volume estimates were obtained in each TG by the application of the optical fractionator (West, 1993) and the planar rotator (Tandrup et al., 1997), respectively, over the same neurons systematically sampled. All measurements were performed using an interactive computer system consisting of a highprecision motorized microscope stage, a $0.5 \mu \mathrm{m}$ resolution $z$-axis reader (microcator VZR 401; Heidenhain, Traunreut, Germany), a solid-state video camera, and a high-resolution video monitor. For cell counting and cell body volume estimation, a planapochromatic $100 \times$ oil immersion lens with a 1.4 numerical aperture (S-Plan Apo 100; Olympus Optical, Hamburg, Germany) was used. The interactive test grids and control of the motorized stage were provided by the CAST stereological software package (Visiopharm, Hørsholm, Denmark) running on a Dell OptiPlex computer (Dell Computer Company, Round Rock, TX).

The fractionator sampling scheme was applied in three successive stages (section series, section area, and section depth), with the total sampling fraction being $\sim 1: 200$, which represents the product of the fractions at each stage. Because variability in section thickness is potentially a significant source of bias, we systematically weighted the contribution of each section to the final number estimate by the number of cells counted in each section (Avendaño et al., 2005). Nevertheless, celloidin sections exhibit a negligible amount of vertical compression and, consequently, low thickness variability within and among sections (Avendaño and Dykes, 1996; West, 1999).

Nucleoli were used as counting units. The Nissl-stained celloidin sections used for counting allowed good discrimination of sensory neurons and their nucleoli along the whole $z$-axis (depth) of the section (supplemental Fig. 1, available at www.jneurosci.org as supplemental material). The presence of two or more nucleoli in each nucleus was explored in all nuclei touching the superior or inferior plane of the counting "box." If two nucleoli were present, only the superior one was taken into account for including or excluding the cell in the counting. An average of 212 neurons was counted in each TG, in a total of 7-14 sections. To assess whether different sampling intensities significantly influenced the results, various sampling schemes were tried in some cases, decreasing the sampling fraction between 4 and 10 times. After crosschecking the estimates obtained in the same ganglia with low ( $\sim 250$ neurons sampled) or high (1500 neurons) sampling schemes, the resulting differences were negligible.

After finding age-related differences in ganglion size and neuron number, estimates of the volume $(V)$ occupied by neuronal somata in the ganglion were obtained by point counting on systematically sampled ganglion sections using the Cavalieri estimator (Gundersen et al., 1988).

The precision of the estimates of $N$ and $V$ were determined by estimating the coefficient of error (CE) as described for systematic random samples (Cruz-Orive, 1999). The different average CEs obtained with this sampling scheme were always below 15 or $5 \%$ for $N$ and $V$ estimations, respectively. The precision of the estimates of $v_{N}$ was evaluated by calculating the coefficient of error using ordinary statistics for independent observations. The CEs for the estimation of $v_{N}$ were always below $8 \%$. Cell and ganglion volume estimates were not corrected for shrinkage.

\section{Search for neuronal proliferation and precursor cells in TG of} adult rats in vivo

Cell proliferation study: animals and tissue processing. For this study, three sets of animals were used. The first group consisted of five 2-month-old male rats that received $0.7 \mathrm{ml}$ intraperitoneal injections of bromodeoxyuridine (BrdU) every $10 \mathrm{~h}$ for 1 week $(40 \mathrm{mg} / \mathrm{ml}$ in $0.1 \mathrm{M}$ Tris- $\mathrm{HCl}, \mathrm{pH}$ 7.5). The second group consisted of four 3-month-old rats that were subjected to right ION transection just before the week-long session of daily intraperitoneal injections of BrdU. The third group was similar to the second, but the rats received an additional week-long series of BrdU injections 3 weeks after transection. Rats from groups 2 and 3 received 50 $\mathrm{mg} / \mathrm{kg}$ BrdU in normal saline per injection.

Rats were killed 3 months after right ION transection in the second and third group and 1-3 months after BrdU injections in the first group by perfusion fixation as indicated above for quantitative studies. TGs from both sides were collected, as were the brain and part of the small intestine. All tissues were postfixed overnight.

Most ganglia were cryopreserved with sucrose at 30\% before sectioning in a freezing microtome at $40 \mu \mathrm{m}$ and were processed for either immunocytochemistry or immunofluorescence. Other TGs were cryostat sectioned at $15 \mu \mathrm{m}$ (on slides) or $40 \mu \mathrm{m}$ (floating) and processed for immunofluorescence staining. One rat from each group was subjected to a retrograde tracing experiment (see below).

Immunocytochemistry for BrdU. TGs and brain sections containing the hippocampus (to serve as positive controls) from three rats were immunoreacted to detect the presence of $\mathrm{BrdU}$-positive $\left(\mathrm{BrdU}^{+}\right)$neurons in TGs. Sections were stained free floating using the following procedure with thorough rinses with PB between steps: (1) pretreatment with $2 \mathrm{~N}$ $\mathrm{HCl}$ at $37^{\circ} \mathrm{C}$ during $20 \mathrm{~min}$ to denature DNA; (2) incubation in blocking solution $[\mathrm{PB}, 2 \%$ bovine serum albumin (BSA), and $5 \%$ normal horse serum] for $30 \mathrm{~min}$; (3) overnight incubation with monoclonal mouse anti-BrdU (Bu20a Clon, MO744; DakoCytomation, Carpinteria, CA) 1:200 in blocking solution; (4) incubation with horse anti-mouse biotin- 


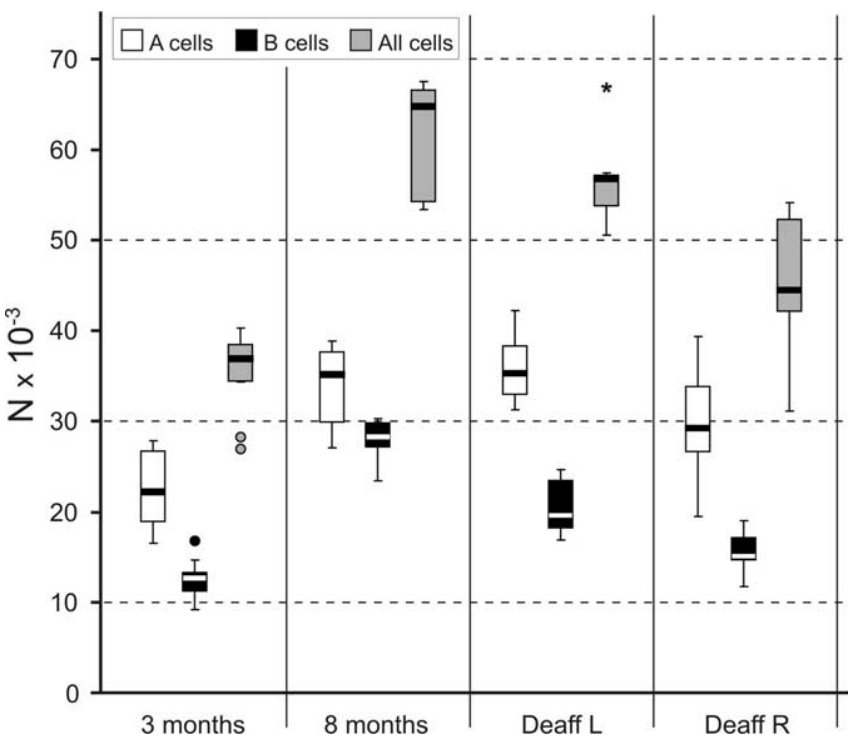

Figure 1. Number of cells per class and side in the TG at different ages. TG sensory neurons nearly double from 3 to 8 months of age $(p<0.001)$. This increase is significant for both major classes, A and B, of ganglion neurons ( $p<0.01$ ), but it is greater for B-type cells (small neurons), which nearly triple with aging. In 7-month-old animals that sustained a transection of the right ION at 3 months of age, the deafferented TG shows a decrease both in A- and B-type cells, the latter being more severely affected ( $p<0.01$ for B-type cells; $p<0.05$ for all cells). The nondeafferented left TG at 7 months shows fewer B-type cells than controls at 8 months $(p<0.01)$. Circles and asterisk mark outliers.

ylated antibody (1:200) in blocking solution; (5) incubation in avidinbiotin-peroxidase complex (ABC) (1:250; Vector Laboratories, Burlingame, CA) in PBS for $90 \mathrm{~min}$; and (6) incubation in diaminobenzidine (DAB) $(0.05 \%$; Sigma, St. Louis, $\mathrm{MO})$ in PBS, with $\mathrm{H}_{2} \mathrm{O}_{2}$ added $(0.003 \%$ of the stock $30 \%$ solution). When the intensity of the staining was satisfactory, the reaction was stopped by rinsing the slides several times in cold PB. Sections were then counterstained with thionin, and finally they were dehydrated, defatted, and coverslipped.

Fast Blue tracing and processing for BrdU immunofluorescence. To determine whether any of the positive BrdU cells sustained axons toward the periphery, 5\% Fast Blue (FB) (EMS-Polyloy, Grossumstadt, Germany) in $\mathrm{DH}_{2} \mathrm{O}$ was applied for $2 \mathrm{~h}$ to the proximal stump of the just severed ION. This procedure was performed bilaterally in one rat in which 1 week BrdU injections had been performed 3 months before. It was also applied in the left ION in another two rats in which the right ION had been transected before BrdU injections. To deposit the tracer, the IONs were exposed and cut, and the proximal stumps were introduced in a plastic vial containing the FB solution. Five days later, the rats were perfused transcardially with $4 \%$ paraformaldehyde. The ganglia and brains were sectioned in a freezing microtome at $40 \mu \mathrm{m}$. All sections were processed for BrdU labeling. This was performed by repeating steps 1-3 of the protocol above for BrdU immunocytochemistry, followed by incubation in rhodamine-conjugated donkey anti-mouse (1:100; Millipore, Temecula, CA). The TGs not used for tracing experiments were used for double fluorescence immunolabeling for BrdU and neuron-specific enolase (NSE) [a universal marker for primary sensory neurons (Vega et al., 1990)] and protein gene product 9.5 (PGP9.5) (for source and dilution of primary antibodies, see Table 2 ).

Immunocytochemistry and immunofluorescence for precursor cell markers. TG sections from several 2-month-old rats were processed with different combinations of primary and adequate secondary antibodies for immunocytochemistry or immunofluorescence (Table 2). For immunocytochemistry, biotinylated secondary antibodies and standard reactions in $\mathrm{ABC}$ and DAB were used. Double-labeling studies were performed using non-cross-reacting secondary antibodies after adequate primary antibody incubation.

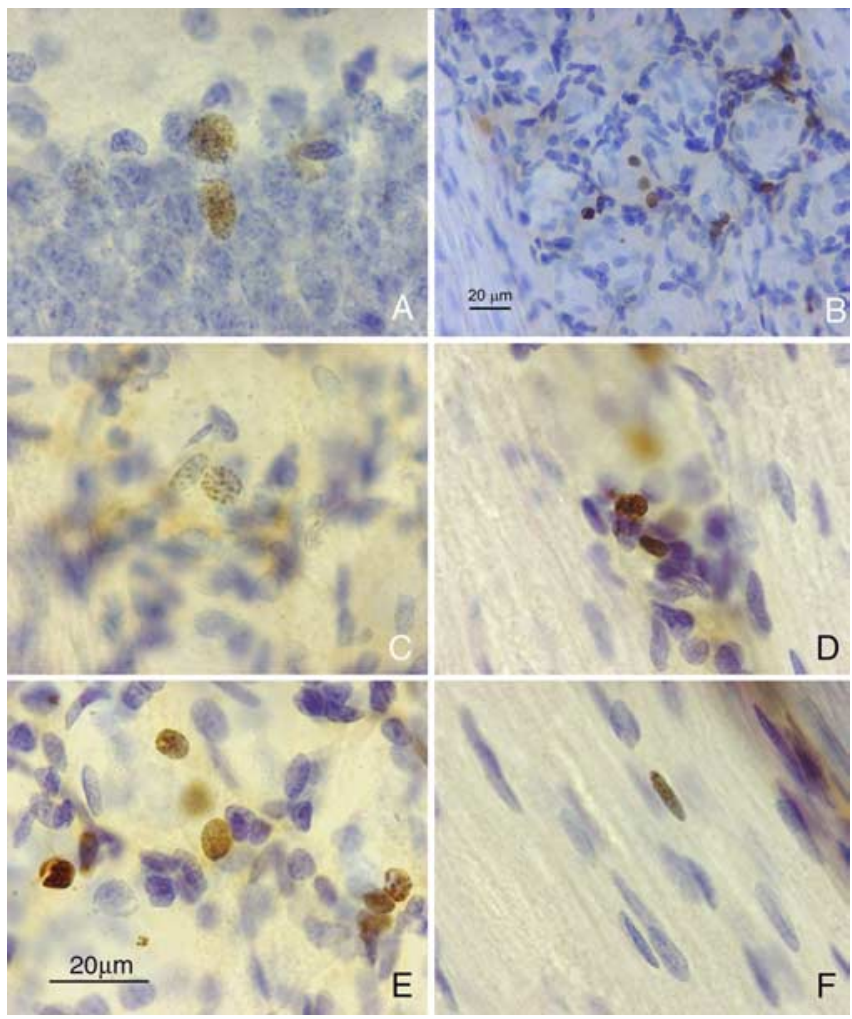

Figure 2. BrdU immunohistochemistry in $\mathrm{TG}$ and rat hippocampus. $A-F$, Photomicrographs of 40- $\mu \mathrm{m}$-thick BrdU-immunoreacted and thionin-counterstained sections from rat hippocampus $(\boldsymbol{A})$ and TG $(\boldsymbol{B}-\boldsymbol{F}) 3$ months after BrdU administration. Immunoreactive nuclei in the TG are all small and are mainly situated around apparently "empty" spaces corresponding to sensory neuron bodies, which stain very weakly with thionin after BrdU processing. Satellite cells display different degrees of immunolabeling. A positive presumed Schwann cell nucleus in a nerve fascicle in the ganglion is shown in $\boldsymbol{F}$. Scale in $\boldsymbol{E}$ also applies to $\boldsymbol{A}, \boldsymbol{C}, \boldsymbol{D}$, and $\boldsymbol{F}$.

\section{Isolation and characterization of neural crest progenitors from}

TGs in adult rats in vitro

Adult Sprague Dawley rats were killed with an overdose of halothane before perfusion through the heart with cold sterile saline to flush the blood cells from the system before tissue dissection at room temperature $\left(20-25^{\circ} \mathrm{C}\right)$. Isolated TGs were pooled in a Petri dish containing Dulbecco's modified HBSS (D-Hanks') solutions (Invitrogen, Carlsbad, CA) on ice. TGs were cleaned of nerve fibers, connective tissues, and capsule membranes, rinsed, and transferred to a separate Petri dish. Tissues were then cut into small blocks $\sim 1-2 \mathrm{~mm}^{3}$. After three washes, explants were suspended in chemically defined proliferation culture medium (PCM) for neural crest stem cells expansion based on previous reports (Kruger et al., 2002), with a few modifications. The constituents of PCM are as follows: Neurobasal-A (Invitrogen) with L-glutamine (0.5 mM), penicillin G, streptomycin sulfate, amphotericin B (1:100; Invitrogen), B-27 (1:50; Invitrogen), N2 (1\%; Invitrogen), recombinant human basic fibroblast growth factor (bFGF) (40 ng/ml; Peprotech, Rocky Hill, NJ), recombinant human epidermal growth factor (EGF) $(40 \mathrm{ng} / \mathrm{ml}$; Peprotech), BSA $(100 \mu \mathrm{g} / \mathrm{ml})$, and heparin sodium from porcine mucous (5 $\mathrm{IU} / \mathrm{ml}$ ) (David Bull Laboratories, Mulgrave, Victoria, Australia), retinoid acid $(110 \mathrm{nM})$, and 2-mercaptoethanol $(50 \mu \mathrm{M})$. Cells were cultured in uncoated T-25 culture flasks at $37^{\circ} \mathrm{C}$ in a humidified atmosphere with $5 \%$ $\mathrm{CO}_{2}$. Fresh bFGF and EGF were added twice each week. Floating single cells migrating out of tissue blocks were observed $1 \mathrm{~d}$ after culture and formed clusters or spheres within 1-2 weeks. Clusters or spheres combined with free-floating single cells were collected from the original culture flask and triturated with a fire-polished Pasteur pipette, and the resultant cell suspensions were passed through a $70 \mu \mathrm{m}$ strainer (Falcon, Franklin Lakes, NJ), after which they were reseeded at 100,000 cells $/ \mathrm{ml}$ into additional tissue culture flasks in PCM to exclude the explants. Half 
of the medium was changed every $3 \mathrm{~d}$, and the changed medium was centrifuged, filtered, and stored as the conditioned medium for selfrenewal analysis (see below). To improve cell expansion, some culture flasks were tightly capped during incubation unless changing medium; this procedure was expected to decrease the oxygen level, which is shown to be beneficial for sphere forming and maintenance of undifferentiated state (Morrison et al., 2000; Studer et al., 2000; Lin et al., 2006).

Self-renewal assay. Spheres/clusters (primary) originally cultured in flasks without explants were triturated with a fire-polished pipette, and the cells were passed through a $40 \mu \mathrm{m}$ cell strainer to create a single-cell suspension. Cells were reseeded in cloning medium which consists of PCM diluted 1:1 with the conditioned medium at a density of 5000 cells $/ \mathrm{ml}$. After 7-10 d culture, some large size spheres (secondary) were selected and dissociated by treatment with AccutmaxTM as demonstrated by Wachs et al. (2003), and the same low-density methods (5000 cells $/ \mathrm{ml}$ ) was used for identification of the formation of tertiary sphere to demonstrate the self-renewal capability. When indicated, this process was repeated to form tertiary and quaternary spheres/clusters.

To further identify the proliferation capabilities of adult TG-derived cells, the primary culture without explants were transfected with the supernatant of Moloney murine leukemia virus-enhanced green fluorescent protein (EGFP) retroviral vector (kindly provided by Dr. Andrew Zannettino, Department of Hematology, Hanson Institute and Institute of Medical and Veterinary Science, Adelaide, South Australia, Australia). EGFP gene expression is driven by the promoter/enhancer sequences of the Moloney murine leukemia virus derived ( 5 ' long-terminal repeat) supplemented with $5 \mu \mathrm{g} / \mathrm{ml}$ Polybrene, at a multiplicity of infection of $\sim 100$ infectious units for $24 \mathrm{~h}$, the resulting cultures were freed of vector by spin pellet and several D-Hanks' washing. Successful incorporation of the transgene into cells was confirmed by GFP fluorescence. The transfected clusters/spheres were then disaggregated and reseeded to evaluate self-renewal by formation of secondary GFP-positive spheres/clusters.

Differentiation and settings. For cloning identification, single secondary sphere/cluster from self-renewal assay was placed on laminin- and poly-L-lysine-coated coverslips in 24-well plates (Nalge Nunc, Rochester, $\mathrm{NY}$ ) and then covered with $50 \mu \mathrm{l}$ of DMEM/F-12 (1:1) containing 15\% fetal calf serum (FCS) Invitrogen), supplemented with penicillin/streptomycin and L-glutamine for $30 \mathrm{~min}$ in an incubator to allow the spheres/ clusters attach on coverslips. The attached spheres/clusters were then washed briefly once with differentiation medium (DM) (similar to PCM but with $2 \mu \mathrm{M}$ forskolin added and bFGF and EGF omitted) and cultured for 1 week in $500 \mu \mathrm{l}$ of the same medium with or without $2 \%$ FCS, which is defined as either serum-containing medium or serum-free medium. For phenotype differentiation induced by combination of neurotrophins, the clusters/spheres plated on poly-L-lysine- and laminin-coated coverslips were fed by DM supplemented with a set of growth factors at $50 \mathrm{ng} / \mathrm{ml}$ including recombinant human-NGF (Peprotech), brainderived neurotrophic factor (BDNF) (Regeneron Pharmaceuticals, Tarrytown, NY), and glial growth factor 2 (gift from Dr. Mark Marchionni, Cambridge NeuroScience, Cambridge, MA), cultured for 1 week, and then fixed and processed by double staining of neuronal and glial markers [neurofilament $200 \mathrm{kDa}$ isoform (NF200) and glial fibrillary acid protein (GFAP)].

Sample preparation for immunostaining. For cell culture, cells were fixed by $4 \%$ paraformaldehyde with $2 \%$ sucrose for $30 \mathrm{~min}$ at room temperature or acid/ethanol $(5: 95 \mathrm{v} / \mathrm{v})$ for $15 \mathrm{~min}$ at $-20^{\circ} \mathrm{C}$ according to the antigens revealed and processed for immunofluorescent staining. For cell smear, the free-floating spheres or clusters were collected by centrifuge and washed with D-Hanks' solution (without phenol red) several times, and the resultant cell suspensions were spread on the gelatincoated slides as cell smear, fixed by acid/ethanol, and processed for indirect immunofluorescence.

Immunocytochemistry. The generic protocol for immunohistochemistry for cultured cells was used as described previously (Zhou et al., 1996; Kruger et al., 2002), with dilution variations for each antigen. Specifically, double-labeling or triple-labeling experiments were performed by simultaneously incubating samples in appropriate combinations of primary antibodies followed by non-cross-reactive secondary antibodies (Alexa fluorophore-conjugated secondary antibodies; Invitrogen or Millipore) or cyanine-conjugated secondary antibodies [Jackson ImmunoResearch (West Grove, PA) or Millipore]. The sources of primary antibodies used and their concentrations are summarized in Table 2. In some samples, nuclei were counterstained with 4', 6-diamidino-2phenylindole (DAPI). The specificity of the light microscopic immunocytochemical procedures was validated by omitting the primary antibodies or by using nonimmune serum instead of the primary antibodies.

RNA extraction and semiquantitative reverse transcription-polymerase chain reaction. Total RNA was isolated from the cultured secondary spheres/clusters derived from adult TG and positive controls sample [embryonic day 12 (E12) rat embryo] using TRI Reagent (Sigma) according to the protocol of the supplier. Semiquantitative reverse transcription (RT)-PCR was performed with duplication on each gene (Table 3 ) as described previously (Chie et al., 2001) with slight modifications. Briefly, the purity and concentration of RNA were assessed by spectrophotometer. To generate cDNA, $2 \mu \mathrm{g}$ of total RNA were reverse transcribed into cDNA by using SuperScript III reverse transcriptase (200 U; Superscript III first-strand cDNA synthesis kit; Invitrogen) in a total reaction volume of $50 \mu \mathrm{l}$ following the protocol of the supplier. Two microliters of reverse-transcription product was amplified by PCR in a $50 \mu \mathrm{l}$ reaction 

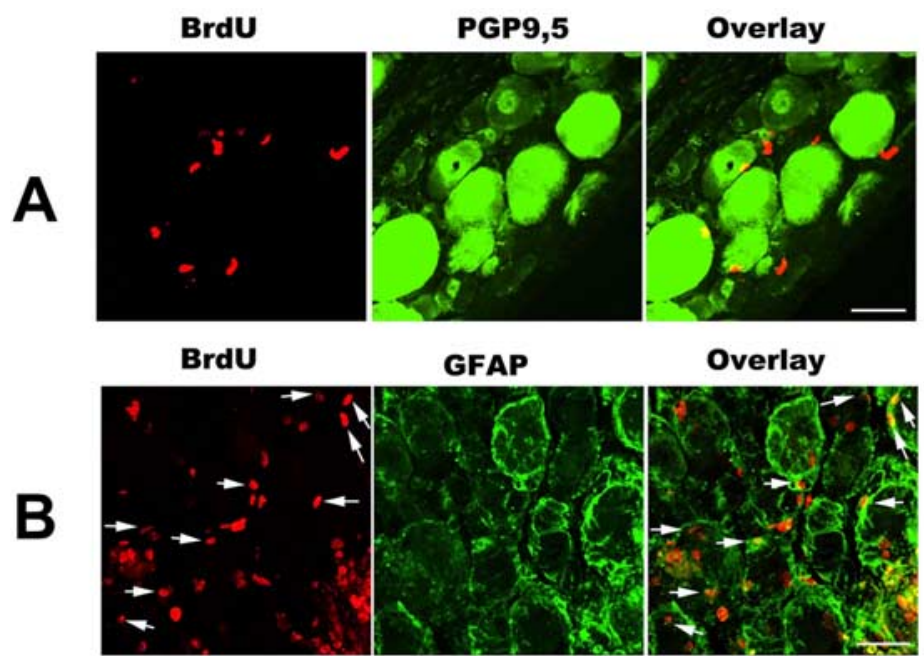

GFAP

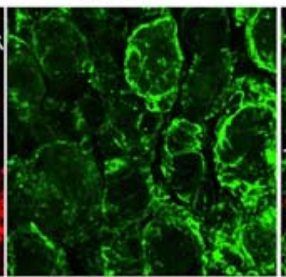

Overlay
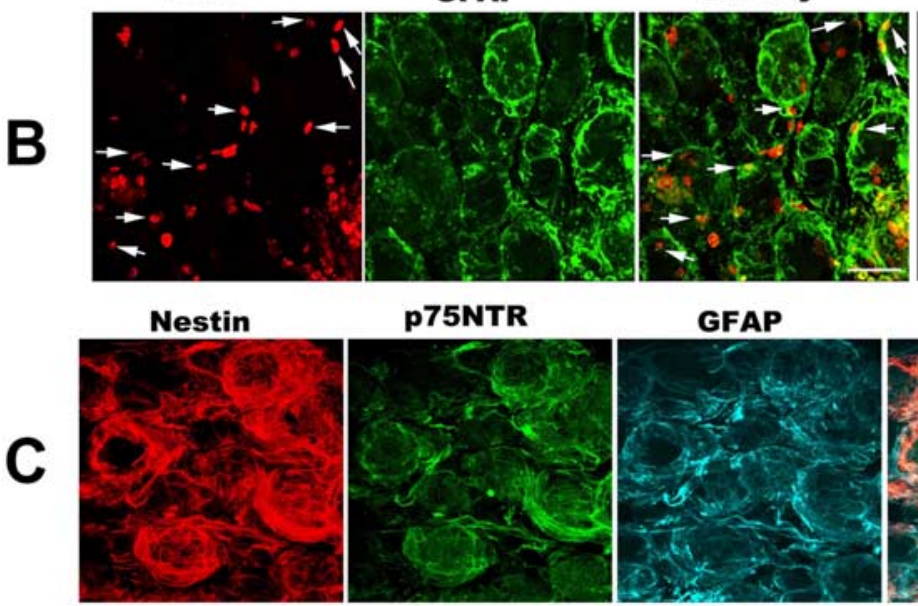

P75NTR
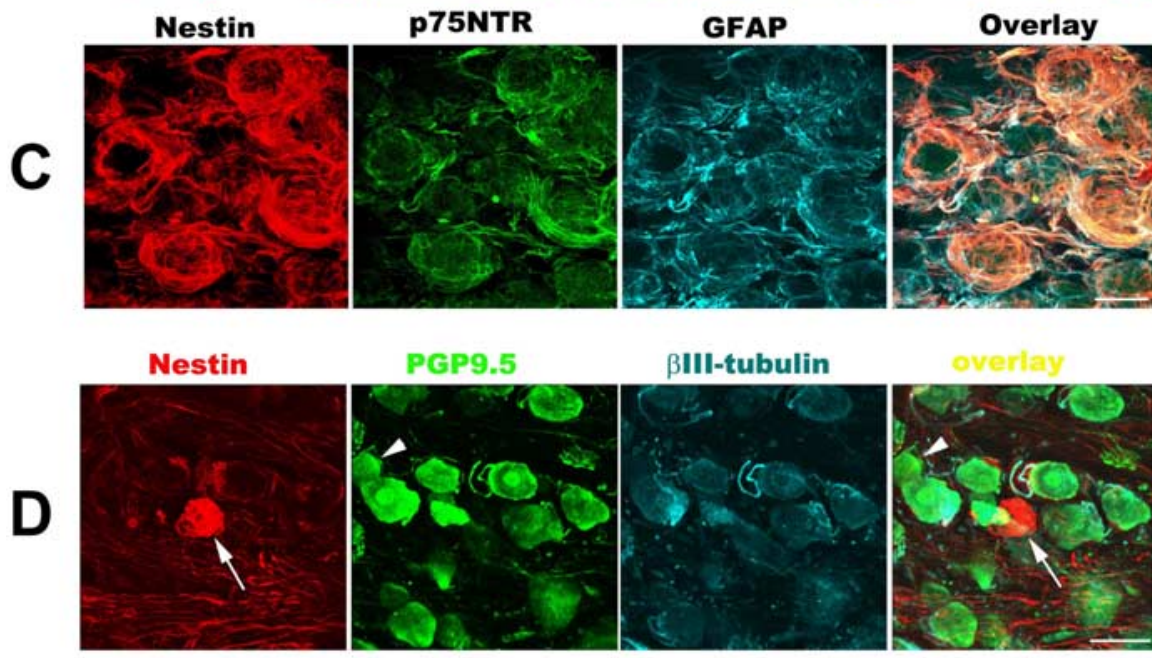

PGP9.5

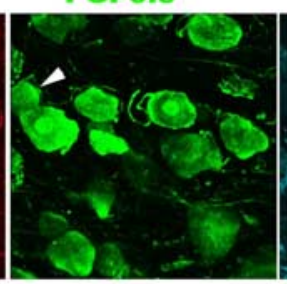

BIII-tubulin
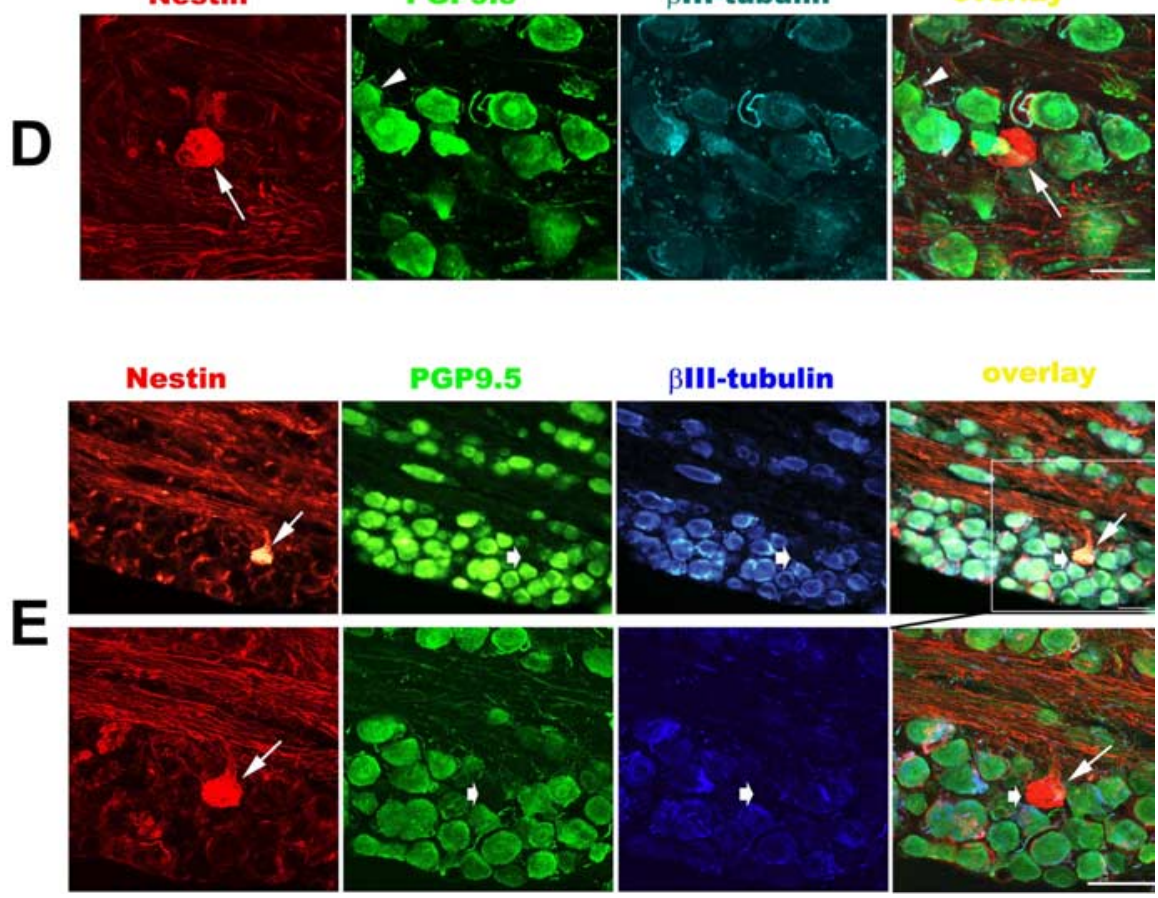

Figure 4. Characterization of $\mathrm{BrdU}^{+}$cells in the $\mathrm{TG} 3$ months after axotomy. $A-D, E$, Bottom row, Three-dimensional constructed images (30 images taken with $60 \times$ oil objectives and $0.5 \mu \mathrm{m} Z$-step for $\boldsymbol{A}-\boldsymbol{C}$, and 25 images taken with $40 \times$ oil objectives and $1.0 \mu \mathrm{m} Z$-step for $\boldsymbol{D}$ and bottom part of $\boldsymbol{E}$ ). $\boldsymbol{E}$, Bottom row, High-magnification image showing the region in the white box in the top row of $\boldsymbol{E}$. $\boldsymbol{A}$ and $\boldsymbol{B}$ show the double labeling for BrdU (red) with PGP9.5 or GFAP (green), and arrows in $\boldsymbol{B}$ indicate $\mathrm{BrdU}^{+} / \mathrm{GFAP}^{+}$colabeling cells. $C$ is a representative confocal image showing that the majority of perineuronal cells coexpressed Nestin (red), p75NTR (green), and GFAP (cyan). $\boldsymbol{D}$ and $\boldsymbol{E}$ are representative photomicrographs taken from different deafferented TGs. The arrowhead in $\boldsymbol{D}$ shows a PGP9.5 ${ }^{+} / \beta$ III-tubulin-negative neuron. In $\boldsymbol{D}$ and $\boldsymbol{E}$, Nestin ${ }^{+}$neuron-like profiles (thin arrows) are negative for PGP9.5/ $\beta$ III-tubulin (thick arrows). Scale bars: $A-C, 25 \mu \mathrm{m} ; \boldsymbol{D}, \boldsymbol{E}, 50 \mu \mathrm{m}$.

volume containing 10 pmol primer sets, $0.25 \mathrm{U}$ of EXTaq DNA polymerase (TaKaRa, Shiga, Japan), PCR buffer ( $\mathrm{pH} 8.4$, final concentrations of $20 \mathrm{~mm}$ Tris- $\mathrm{HCl}, 50 \mathrm{~mm} \mathrm{KCl}, 2.5 \mathrm{~mm} \mathrm{MgCl}_{2}, 10 \mathrm{~mm}$ dithiothreitol, and 1 $\mathrm{mm}$ dNTP). The protocol for the thermal cycler was as follows: denatur-
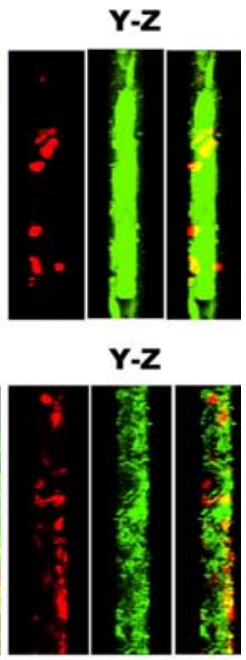

ation at $94^{\circ} \mathrm{C}$ for $5 \mathrm{~min}$, followed by $30-38 \mathrm{cy}$ cles of $94^{\circ} \mathrm{C}(30 \mathrm{~s})$, optimal annealing temperature $(1 \mathrm{~min})$ (Table 3$)$ and $72^{\circ} \mathrm{C}(45 \mathrm{~s})$, with the reaction terminated by a final 10 min incubation at $72^{\circ} \mathrm{C}$. Glyceraldehyde-3-phosphate dehydrogenase $(\mathrm{G} 3 \mathrm{PDH})$ served as the internal control. Control experiments without reverse transcriptase or without template cDNA revealed no nonspecific amplification. PCR products were analyzed on ethidium bromidestained $1.7 \%$ agarose gels. The intensities of signal were scored by five arbitrary units: - , not detectable (no signal); \pm , barely detectable ( $m i-$ nor signal); + , detectable (weak signal); ++ , easily detectable (moderate signal); +++ , strongly detectable (strong signal).

Microscopy and photography. Immunolabeled sections were studied with an Olympus Optical BX-50 microscope or a Nikon (Tokyo, Japan) Eclipse E600W, using planapochromatic lenses for bright field, and fluorescence lenses and appropriate filters for immunofluorescence. Photomicrographs of selected fields were performed with a Nikon DXM 1200, 12bit digital camera. Sections from doublelabeling experiments were also studied in a confocal microscope (TCS SP2-DM IRE2; Leica, Nussloch, Germany), using argon laser (exciting at $488 \mathrm{~nm}$ ), helium-neon laser (exciting at $543-633 \mathrm{~nm}$ ), and argon-UV laser (exciting at 351 and $362 \mathrm{~nm}$ ) or BRC-2000 confocal image system with Lasers harp 2000 acquisition software (model 1024; Bio-Rad, Hercules, CA) for the various fluorescent markers used. The Leica Confocal Assistant program was used for the processing of the images and Corel Photopaint and Corel Draw (Corel, Ottawa, Ontario, Canada) for the digital processing of the images. Only light intensity, brightness, and contrast adjustments were allowed to improve information.

Statistical analysis and cell counting. The number of positive-stained cells was counted using NIH Image J program, and the percentage of total cells expressing a positive marker was determined in three to four coverslips $(>200$ cells) in triplicate experiments. Data were analyzed statistically using the SPSS 12.0 program (SPSS, Chicago, IL) and presented as mean \pm SEM. After checking normality in the distribution and homogeneity of variances, bilateral $t$ tests were applied for intergroup comparisons. Paired $t$ tests were used for side comparisons. Pearson's correlation coefficient was used to assess the relationship between the number of neurons and the volume occupied by them in the ganglion. A significance level was accepted for $p=0.05$.

\section{Results}

Trigeminal ganglion neurons vary with sides, age, and peripheral axotomy

The mean data for ganglion volume and neuronal number and volume from different ages and sides are shown in Table 1. In nondeafferented animals, there is a significant $(p<0.01)$ increase in the number of neurons from 3 months (average, 35,200; range, 25,800-43,000; coefficient of variation, 0.16 ) to 8 months (average, 61,850; range, 51,300- 
69,800; coefficient of variation, 0.09 ) of age. The total number of primary sensory neurons serving the trigeminal system per animal nearly doubles in 5 months (average 3 months, 70,000; 8 months, 123,700). These results are not affected by the extraction or processing of the ganglion, because similar numbers are encountered in ganglia extracted with peripheral nerve and not sectioned along their longitudinal axis while being processed (3-month-old rat, 69,000; 8-month-old rat, 108,400). Regarding neuronal number, no side differences are detected. At 7 months of age, deafferented animals show in the intact side a nonsignificant $10 \%$ lower number of neurons than the same side in 8-monthold controls (56,500 vs 62,900). However, in the injured TG, there is a significant $(p<0.05) 29 \%$ decrease in the number of cells compared with the same side in 8-month-old controls, or $20 \%$ compared with the contralateral (intact) side in the same 7-month-old group. Mean neuronal volume does not change with age, but the volume occupied by cells in the ganglia increases also from 3 to 8 months of age $\left(1.25\right.$ vs $\left.2.09 \mathrm{~mm}^{3} ; p<0.05\right)$. There is a strong correlation between neuronal numbers and the volume occupied by them in the ganglion (Pearson's $r=0.898 ; p<0.001$ ), supporting the real increase in neuron number. Mean neuronal volume, however, is clearly larger in the right side, at both 3 and 8 months $(p<0.05)$. This difference disappears by deafferentation.

The distribution of changes among the different cellular types also varies with age and experimental manipulation (Fig. 1). B-type cells are more profoundly affected, because the number of small cells more than doubles from 3 to 8 months of age (154\% increase), whereas the increase of A cells remains at 50\%. The percentage of cells of each class changes accordingly, from a 66:34 $\mathrm{A} / \mathrm{B}$ ratio at 3 months to a 55:45 ratio at 8 months. Deafferented animals show in their nonoperated side no significant differences with the 8 month controls for the whole population and the A-type neurons; however, the number of B-type neurons is moderately lower in the deafferented group $(p<0.05)$. In the lesioned side, however, both neuron types contribute to the significant $(p<0.05$ ) overall $20 \%$ difference with the contralateral side mentioned above. This neuronal loss affects more severely B cells (24\% fewer than control side) than A cells (17\% fewer than control side).

\section{Lack of neuronal proliferation in vivo}

BrdU was clearly taken up by cell nuclei in the TG (and deeper part of the granular layer of the dentate gyrus), as shown in Figures $2-4$. The vast majority of these nuclei corresponded to glial cells, given their size, shape, and loss of cytoplasmic counterstaining with thionin (Fig. 2). Most presented a perineuronal distribution, consistent with them being satellite cells, because they also express p75NTR, Nestin, and GFAP (Fig. $4 B, C$ ) but not with the neuronal marker PGP9.5 (Fig. $4 A$ ). To prevent a small number of neuronal nuclei having been overlooked in single-labeling studies, double-labeling studies were performed with FB and NSE (Fig. 3). No FB ${ }^{+}$BrdU $^{+}$double-labeled cells were identified, and only a few $\mathrm{NSE}^{+} \mathrm{BrdU}^{+}$cells were very rarely found, even after intensive BrdU injection protocols.

Identification of possible delayed neuronal maturation in the TG of the adult rat: doublecortin- and Nestin-positive cells in the TG in vivo

Because of the lack of evident neuronal proliferation that could be responsible for the increase in the number of neurons, we looked for markers that could indicate delayed neuronal maturation such as Islet 1/2, Nestin, and doublecortin (DCX). Nestin immunoreactivity normally is present around ganglion cells, corresponding to glial profiles. However, there is in addition a small cell population expressing nestin in their cytoplasm, which resemble small neurons of bizarre appearance but do not express neuronal markers $\beta$ III-tubulin or PGP9.5 (Fig. $4 D, E$ ). DCX ${ }^{+}$ small cells are found predominantly in the peripheral nerve in both the maxillary and mandibular branches, interspersed with the nerve fibers or in the perineurium (Fig. 5). These cells are arranged in loose linear aggregates. The possibility that these Nestin $^{+}$or $\mathrm{DCX}^{+}$cells expressed mature pan-neuronal markers was tested by triple labeling of Nestin ${ }^{+}$cells with PGP9.5 and $\beta$ IIItubulin (Fig. $4 A$ ) and double-labeling of $\mathrm{DCX}^{+}$cells with NSE (Fig. $6 A-C$ ). None of the $\mathrm{Nestin}^{+}$or $\mathrm{DCX}^{+}$cells presented coexpression of any neuronal marker in TG, whereas the majority of $\beta$ III-tubulin ${ }^{+}$labeling colocalized with PGP9. $5^{+}$expression (Fig. 4D). Also, in tracing studies, the presence of FB was thoroughly looked for in $\mathrm{DCX}^{+}$cells, but none of them were double labeled (Fig. 6D).

\section{Isolation and characterization of neural crest progenitors from trigeminal ganglion in adult rats in vitro}

Cells emigrated from adult TG have the ability to form clusters/ spheres with limited self-renewal capacity

To elucidate the existence of progenitors in the adult TG, we initially dissociated fresh TG into single cells and cultured them in PCM. Despite repeated efforts, we failed to identify any spheres 

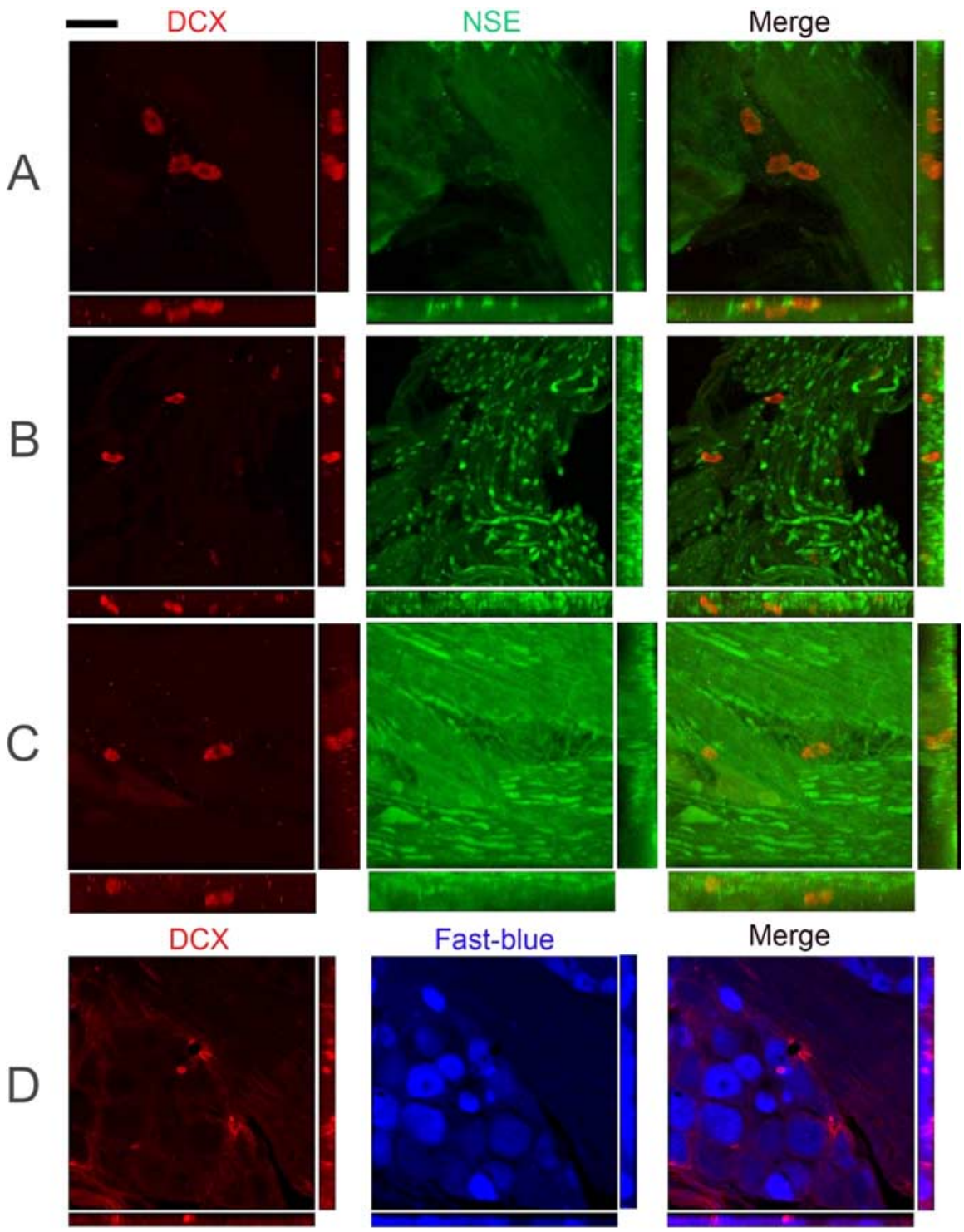

Fast-blue
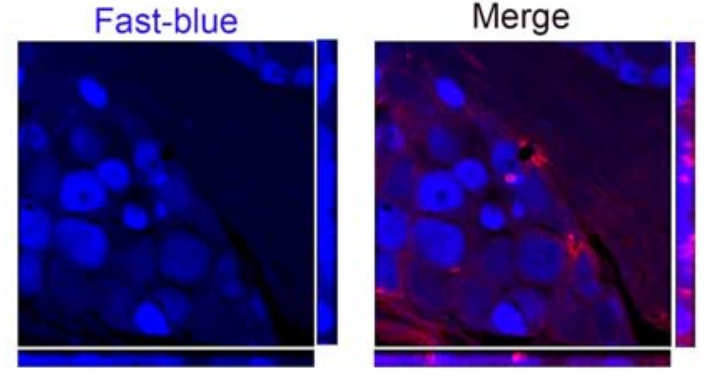

Figure 6. Double immunofluorescence for DCX-NSE and DCX-Fast Blue in the TG and trigeminal nerve branches. Confocal microscopy of 40- $\mu \mathrm{m}$-thick sections from rat TG. $\boldsymbol{A}-\boldsymbol{C}$, Examples of $D C X^{+} /$NSE-negative cells interspersed with $\mathrm{NSE}^{+}$nerve fibers. $D, A$ small $D C X^{+}$cell is surrounded by Fast Blue ${ }^{+}$cells. No double-labeled cells were found in any case. Scale bar (in top left): $\boldsymbol{A}, \boldsymbol{C}, 34 \mu \mathrm{m} ; \boldsymbol{B}, 64 \mu \mathrm{m} ; \boldsymbol{D}, 48 \mu \mathrm{m}$.

using this protocol. We then reasoned that, if any progenitor did exist in the adult TG, these cells should have similar intrinsic traits to neural crest cells, i.e., great plasticity and high migratory ability (Le Douarin et al., 2004; Tucker, 2004), especially during mitogen stimulation. Explants culture has been successfully used to identify the behavior of neural crest cells during development in rodents (Greenwood et al., 1999; Lo et al., 2002). Based on this assumption and previous studies, we performed the explants culture to see if any cells migrated out. Within $24 \mathrm{~h}$ of culturing, budding structures (sprouts) (Fig. 7A, arrow) were found at the edges of the tissue blocks, and some migrating cells were detected in the culture medium of TG explants. Three days later, more freely floating cells were observed in the medium. These cells incorporated BrdU from culture medium (data not shown), continued proliferating, and formed clusters and spheres with time. We define clusters as floating aggregates with loosely packed phase-bright cells and spheres as round spherical formations with densely packed dark cells in the center and phase-bright cells in the periphery with a diameter of $>100$ $\mu \mathrm{m}$. Some floating cells were spinning in the culture medium when observed under the microscope. Seven days after explants culture, the number of small clusters with $4-10$ cells was significantly increased (Fig. $7 C$, arrow). The number of cells in the culture increased with culture time, suggesting that cells continued to migrate out from the ganglia and/or proliferating in the culture. Two weeks after culture, dense spheres were seen (Fig. 7D, arrow), and the diameters of most spheres increased by 5 to 10 -fold after culture for 4 weeks (Fig. $7 E$, arrow).

To see whether adult TG-derived cells have a self-renewal capacity, we first tested whether individual cells derived from the spheres could form new spheres. Primary spheres and secondary spheres were dissociated into single-cell suspensions and reseeded at low-density in cloning medium. Immediately after seeding, only individual cells but no clusters were observed. In all cases, clonally derived spheres were visible within 2 weeks after reseeding, although some differentiating cells attached the bottom of culture flasks. Of 25,000 replating cells from the primary spheres and secondary spheres, $25.3 \pm 5.8$ and $34.6 \pm 6.7$ $(n=3)$ new spheres were formed, accounting for the secondary and tertiary sphere-forming efficiency of $\sim 0.10 \pm 0.02$ and $\sim 0.18 \pm 0.03 \%$ (Table 4 ), respectively. New clusters/spheres could be maintained for $>3$ months in the absence of primary explants (a typical secondary sphere is shown in Fig. $7 F$ ). To further demonstrate the proliferating ability of adult TG-derived spheres/clusters and to exclude the possibility of cell-autonomous aggregates forming in low-density cloning, we transfected the primary culture with a retroviral vector with EGFP as a reporter for $24 \mathrm{~h}$. As shown in the bottom of Figure 7, GFP positive primary spheres/clusters appeared in 1 week culture, and the dissociated GFP-positive primary spheres also formed the secondary spheres/clusters with GFP fluorescence. These data showed that a subpopulation of migrating cells from adult TG had a limited capacity to self-renew.

\section{Characterization of adult TG-derived secondary spheres}

We next characterized the secondary clusters/spheres by immunocytochemistry. We examined whether TG-derived clusters/ spheres contained markers for neural crest stem cells, p75 neurotrophin receptor (NTR) (Stemple and Anderson, 1992) and Nestin (Lendahl et al., 1990). Spheres in PCM contained many cells expressing the neural progenitor markers Nestin and neural crest progenitor marker p75NTR (Fig. 8, top panel $A$ ). Among all clusters and spheres examined, all clones expressed Nestin and p75NTR. Confocal image data showed that $75.4 \pm 15.8 \%$ of total cells expressed Nestin and $51.7 \pm 10.9 \%$ expressed p75NTR. These clusters/spheres were also positive for GFAP ( $48.1 \pm 9.5 \%)$ 
(Fig. 8, top panel $B$ ) and these markers partly coexisted. These characteristics persisted in tertiary spheres and even in cultures maintained for up to 3 months.

To examine their differentiation, the secondary spheres were cultured in differentiation conditions after removal of bFGF and EGF. One week after differentiation, the spheres grew on the surface of the coated coverslips as a monolayer and differentiated into different types of cells, as revealed by double- or triple-labeling technique. The differentiated cells from single spheres contained immunoreactivities for neuronal marker (NF200) and/or glial marker (GFAP or S100), and/or smooth muscle cells marker [smooth muscle, $\alpha$-actin (SMA)] (Fig. 8, bottom panel $A)$. After some small-sized spheres adhered and grew out in a monolayer on coverslips with time, most differentiated cells retained Nestin expression, and DCXpositive cells could also be found (Fig. 8, bottom panels B4-B6); neurons with typical long-processes with $\beta$ III-tubulin immunoreactivity were infrequently observed in the sphere-differentiation setting (Fig. 8, bottom panel $C$ ). Thus, single spheres from adult TG have the ability to differentiate into different cell lineages. The expression of neural and mesodermal markers (SMA) in the progeny of spheres demonstrates that the multi-lineage differentiation capacity of emigrating cells form adult TG explants culture.

\section{TG-derived neurospheres expressed} neural crest progenitor-related genes To confirm our immunocytochemical findings and the features of neural crest, we used semiquantitative RT-PCR to analyze the neurospheres and investigate their properties further. Specifically, we examined whether they expressed stem cellspecific genes, proneural genes, as well as neural crest marker genes (Fig. 9). We used RNAs extracted from an E12 rat as a positive control for RT-PCR to eliminate falsenegative results. Adult TG-derived spheres expressed not only a set of neural crest-specific genes [Twist1 (twist homolog 1), FoxD3 (forkhead box D3), and Snail1 (snail homolog 1)] but also a panel of well defined genes involved in the maintenance, proliferation, self-renewal, or migration of adult/embryonic neural stem cell or their niches, including Pax6 (paired box gene 6), Wnt1 (wingless-type MMTV integration site family 1), CXCR4 (chemokine receptor 4), sox2 (SRY-box containing gene 2), sox10, Msi-1 (musashi-1), Id2 (inhibitor of DNA binding 2), and Id4. However, expression levels were undetectable for both Shh (sonic hedge hog) and Notch-1, another two important morphogens in the regulation of adult neural progenitors (Lai et al., 2003; Palma et al., 2005; Yoon and Gaiano, 2005; Alexson et al., 2006; Androutsellis-Theotokis et al., 2006), or for CD133, a commonly used marker for adult hematopoietic stem cells, mesenchymal
3 days

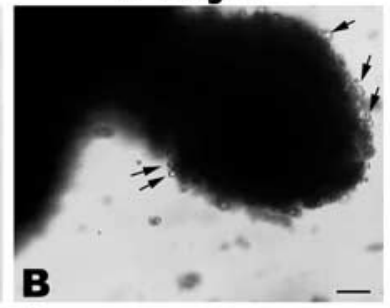

4 weeks

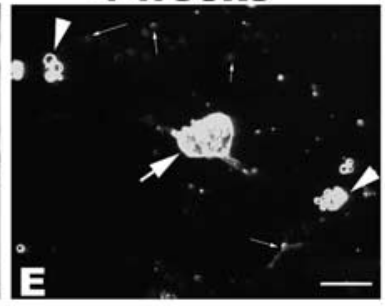

secondary sphere

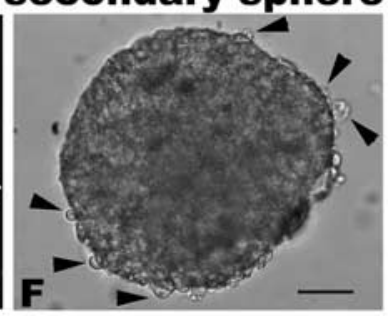

\section{1 week}

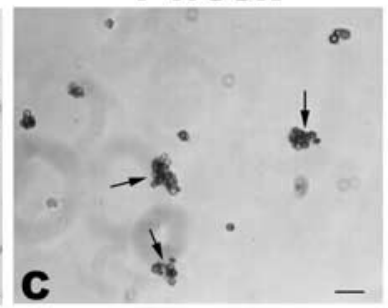

E
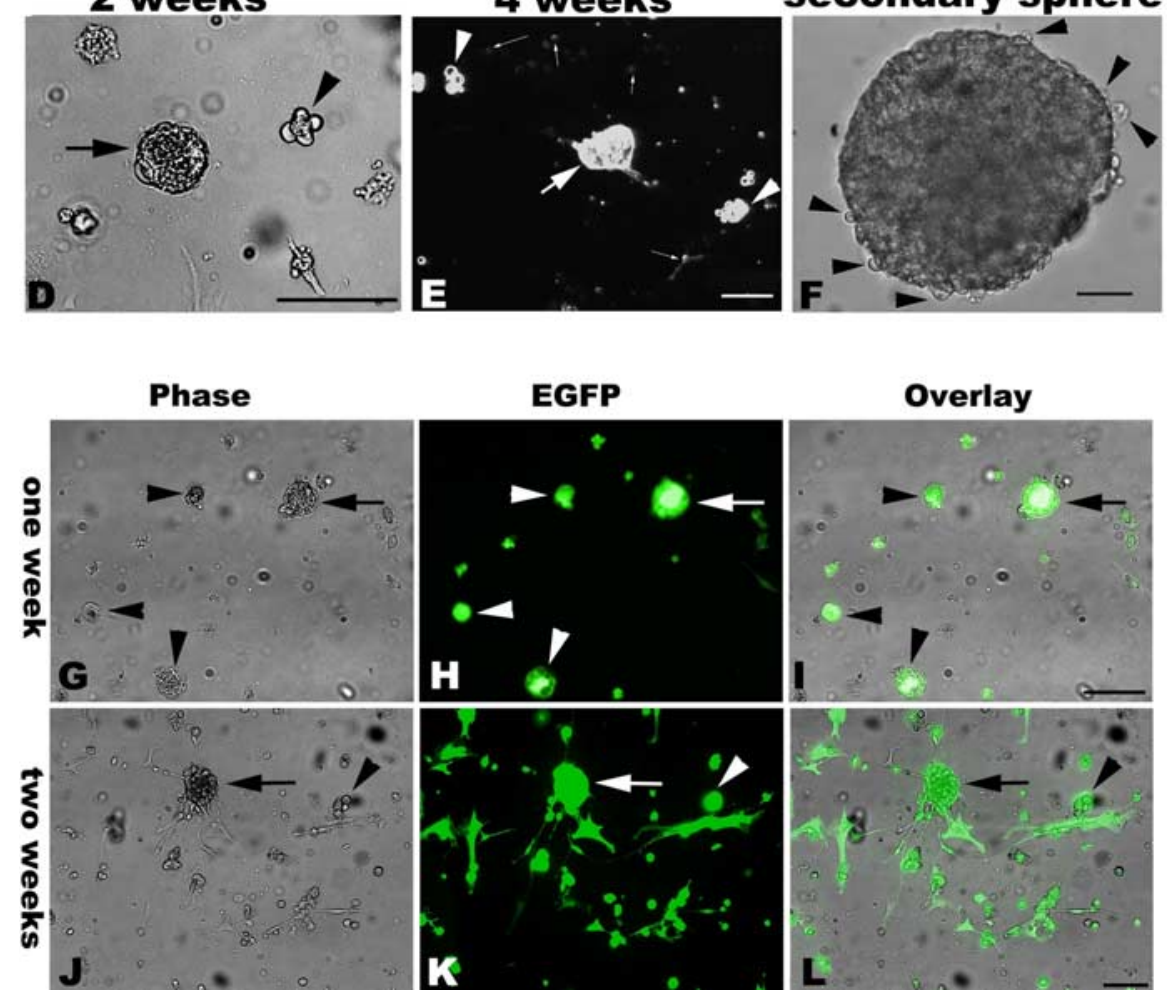
Phase-contrast morphology of emigrating cells and spheres from adult cultured TG. Top, Cells emigrate from TG explants at 1-3 , arrows) in vitro. Sprouting-like cells are seen at the edges of the tissue blocks ( $\boldsymbol{B}$, arrows). After 1 week in culture, loosethe medium. After 2 weeks in culture, a few spherical structures can be found in flasks; the size of these multicellular aggregates (the tight-packed floating cellular aggregates marked by an arrow in $\boldsymbol{D}$ ). free-floating cells (slim arrows) are still predominant after 4 weeks in culture. Scale bar, $100 \mu \mathrm{m}$. Bottom, Green fluorescent primary spheres (arrows)/clusters (arrowheads) are found 1 week after retroviral EGFP vector transfection (G-I). The dissociated cells from EGFP-transfected sphere/clusters also form secondary GFP ${ }^{+}$spheres/clusters as shown by arrows and arrowheads, respectively $(\boldsymbol{J}-\boldsymbol{L})$. Scale bar, $100 \mu \mathrm{m}$.

Table 4. Sphere-forming efficiency by low-density subcloning.

\begin{tabular}{lll}
\hline & Primary $\rightarrow$ secondary & Secondary $\rightarrow$ tertiary \\
\hline Spheres $(\%, n=3)$ & $25.3 \pm 5.8(0.10 \pm 0.02 \%)$ & $34.6 \pm 6.7(0.18 \pm 0.03 \%)^{*}$ \\
\hline
\end{tabular}

Five milliliter single-cell suspensions derived from primary/secondary spheres in cloning medium were inoculated into $25 \mathrm{~cm}^{2}$ flasks ( $5000 \mathrm{cell} / \mathrm{s} / \mathrm{ml}$ ), and bFGF and EGF were supplemented into flasks every $3 \mathrm{~d}$. Two weeks later, the total number of spheres was acquired under microscope by counting the spheres resuspended in $100 \mu$ I of medium in one well of 96 -well plate per flask. The primary sphere was defined by the first appearance in primary culture freed from explants, after dissociation, the single-cell from primary spheres can form new spheres, and the resulted spheres called the secondary spheres; similarly, the tertiary spheres were defined by the formed spheres from the picked secondary sphere. Data show the total mean number (average percentage of counted number of spheres) in 25,000 cells with the mean \pm SEM. ${ }^{*} p<0.05$, significant differences between the ratio of the secondary spheres and the ratio of the tertiary spheres (paired $t$ test).

stem cells, and adult CNS-derived stem cells (Kania et al., 2005; Lee et al., 2005; Marzesco et al., 2005; Bao et al., 2006). Clear expression of proneural genes of basic helix-loop-helix family members [Mash1 (mammalian achaete-schute homolog 1), 


\section{Upper}
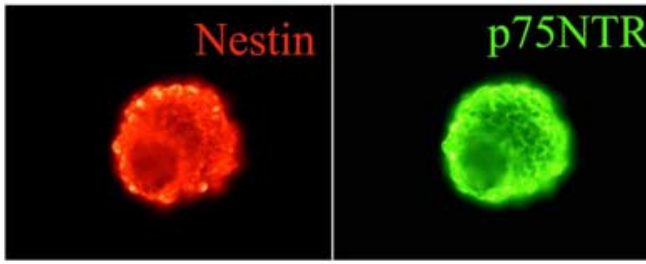

$\mathbf{A}$
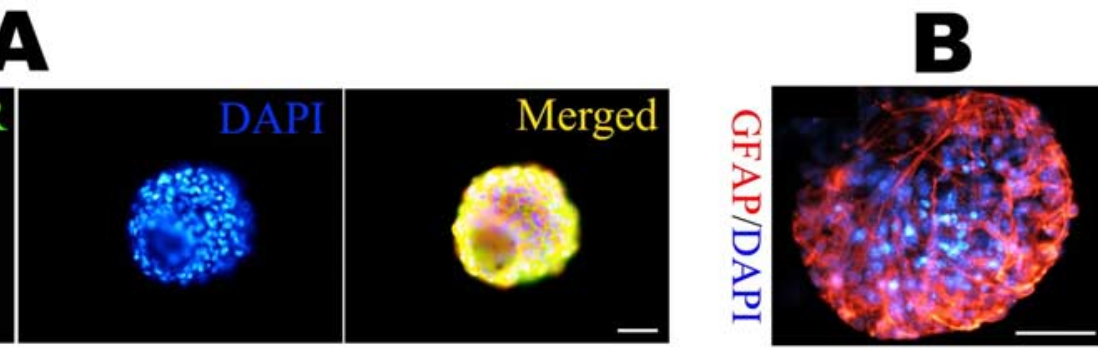

\section{Lower}
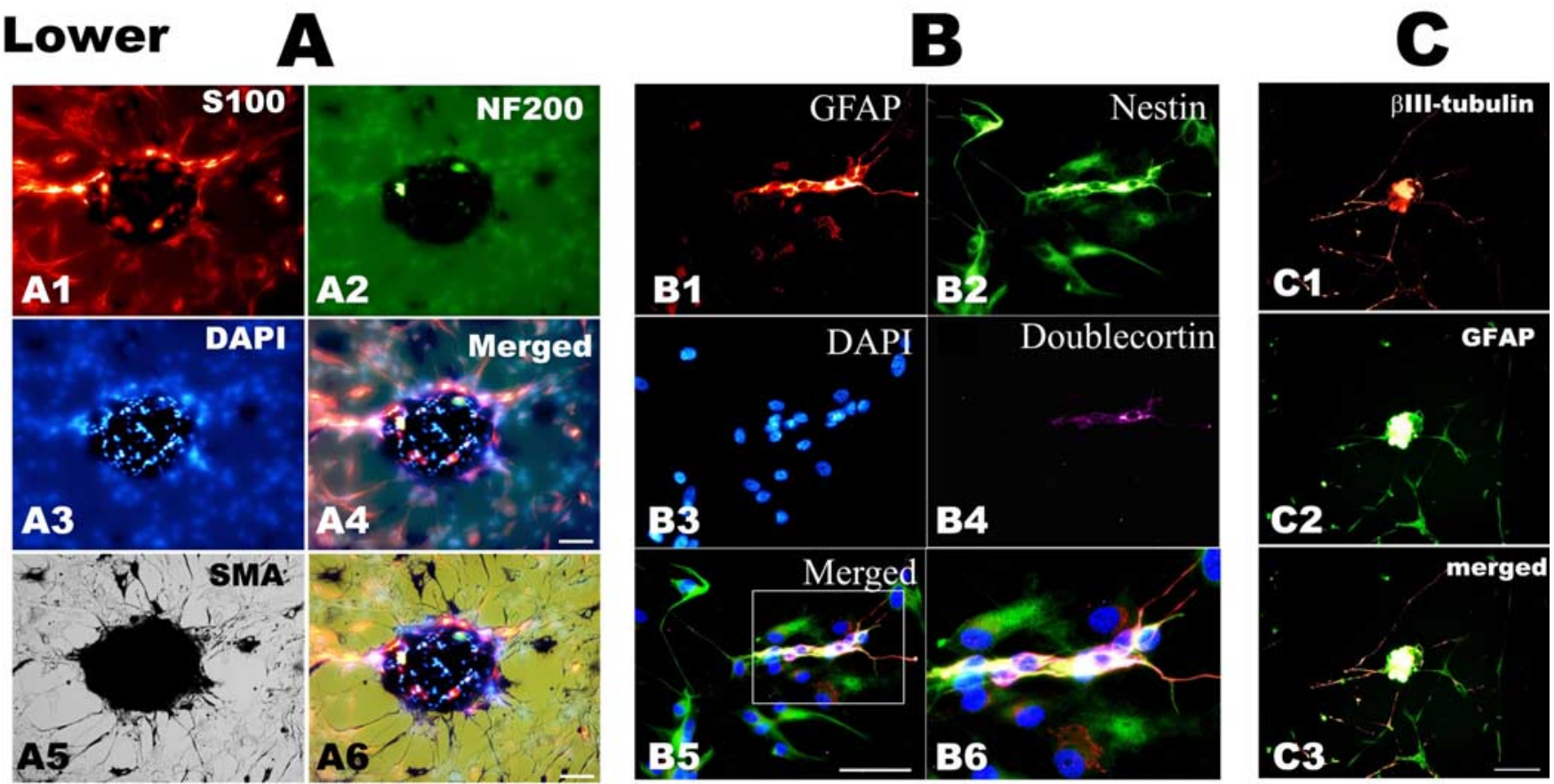

Figure 8. Characterization by immunofluorescence of the secondary spheres derived from adult TG explants. Immunohistochemical characterization of neurospheres derived from adult rat TG explant cultures. Top, $\boldsymbol{A}$, Representative photomicrographs show that spheres express Nestin and p75NTR; $\boldsymbol{B}$, another sphere was stained for GFAP, and nuclei were counterstained by DAPI. Bottom, Immunocytochemistry staining for lineage markers on 2 week differentiation culture of hand-picked secondary spheres in DM. $\boldsymbol{A}$, The same field image showing $S 100$ ( $\boldsymbol{A}$, red), NF200 (A2, green), and SMA ( $\boldsymbol{A} \mathbf{5}$, black by DAB development) labeling; $\boldsymbol{A} \mathbf{4}$ is the merged image of $\boldsymbol{A} \mathbf{1}-\boldsymbol{A} \mathbf{3}$, and $\boldsymbol{A} \mathbf{6}$ is the overlay micrograph of $\boldsymbol{A} \mathbf{4}$ and $\boldsymbol{A} \boldsymbol{6}$. $\boldsymbol{B}, \boldsymbol{A}$ representative staining of GFAP (B1, red), Nestin (B2,

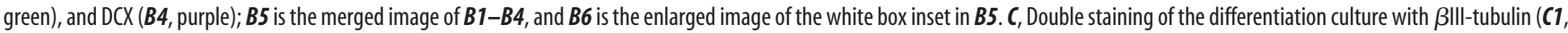
red) and GFAP ( $\mathbf{2}$, green); $\mathbf{C}$ is the merged image of $\mathbf{C}$ and $\mathbf{C}$. Scale bar, $50 \mu \mathrm{m}$.

NeuroD (neurogenic differentiation), and Ngn1 (neurogenin homolog 1)], sensory neuron-specific transcription factor [Brn3a (Pit1-Oct1-Unc86 domain, class 4 transcription factor 1 [Pou4f1])], and glial transcriptional factors [EGR2 (early growth response 2), also called Krox-20, and sox10], along with low-level expression of neuronal specific-gene repressors, REST (RE1silencing transcription factor) and coREST (REST corepressor), was obtained, in concord with the neuronal and glial differentiation potential of TG-derived spheres. The very weak expression of both the embryonic stem cells marker Oct4 (octamer-binding transcription factor 4) (Nichols et al., 1998; Loh et al., 2006) and the adult stem cell self-renewal gene Bmi-1 (B lymphoma MoMLV insertion region 1) (Molofsky et al., 2003, 2005) might, respectively, exclude the possibility of primitive reserve stem cells and be consistent with the limited proliferation capacity of the emigrating sphere-forming cells from adult TG. The low-level expression of self-clearing/autophagy genes [Beclin1 and MAPLC3 (microtubule-associated protein 1 light chain 3)] might indicate the dynamic turnover of sphere-forming cells. The geneexpression profile is quite consistent with the identified features by cloning analysis and immunocytochemistry, which are migra- tory, limited self-renewal, neural-lineage differentiation, and adult neural crest origin.

\section{Discussion}

The present study demonstrates that there is an important increase in the number of neurons of the TG of the adult male rat with age. B-type cells are the most affected population, although A-type cells also increase in number. This increase is accompanied by an increase in the volume fraction of ganglion occupied by cell bodies, because mean neuronal size does not vary. Side differences in neuronal volume, but not number, appeared in 8-month-old ganglia, as reported previously for 3-month-old rats (Lagares and Avendaño, 2000).

Neuron numbers increase with age in the TG of adult rats: methodological considerations

So far, the number of neurons in the rat TG has seldom been investigated, and the few published reports reveal notable differences (Aldskogius and Arvidsson, 1978; Forbes and Welt, 1981; Biedenbach et al., 1992; Lagares and Avendaño, 2000) In DRG, postnatal age-dependent variations in neuron numbers have 
been alternatively disputed or ratified, mainly within a debate on counting methods (Devor and Govrin-Lippmann, 1985, 1991; Coggeshall et al., 1990; Coggeshall, 1991; La Forte et al., 1991). Recent stereological studies have confirmed the fact of neuron addition in adult rat DRG (Cecchini et al., 1993, 1994, 1995; Popken and Farel, 1997; Ciaroni et al., 2000; Farel, 2002).

Care was therefore taken to ensure that the whole measuring process was robust, as a necessary condition to ensure reliable results. Stereological methods are mathematically unbiased, but estimation inaccuracies may emerge from the various artifacts generated during tissue processing and observation (Avendaño, 2006). The optical fractionator is resistant to those additional sources of bias, because it makes counting independent of the reference space (West et al., 1991), and this gives the method an edge over the physical disector. However, it still is sensitive to changes in tissue shrinkage and other deformations that occur along the section depth, and they must be accounted for when counting (Lagares and Avendaño, 2000; DorphPetersen et al., 2001; Bermejo et al., 2003).

To discard uncontrolled biases in the observer, counting on the same material was repeated independently by two authors (A.L. and C.A.), obtaining negligible differences. Also, the total number of neurons $N$ was indirectly estimated by estimating the overall volume $(V)$ occupied by neuron bodies in the ganglion and dividing it by the mean neuronal volume, $v_{N}$. Again, no significant differences emerged. Another possible source of error could come from neurons sitting outside the limits of the ganglion in young animals, which could eventually relocate inside with time. Such misplaced sensory neurons are occasionally found in spinal nerves or roots outside the DRG (our unpublished observations). However no such neurons were found after thoroughly analyzing all of the trigeminal root and nerves that remained attached to the TG. Finally, the use of nucleoli as counting units is advantageous if care is taken to avoid oversampling of cells with more than one nucleolus. An undercounting problem could also emerge, should some cells lack a distinctive nucleolus. Such situation would be very rare in cells with enough Nissl-based cytoplasmic features to enable them being recognized as neurons. However, the problem could be genuine for immature cells lacking other neuronal phenotypical features (see below).

In the present study, we found that not all neuron types contribute in the same manner to the numerical increase of TG neurons. B-type cells double their number from 3 to 8 months of age, whereas A-type neurons show a relatively modest $50 \%$ increase. After unilateral ION transection, the affected TG shows a mild and nonsignificant decrease of large neurons but a larger, and

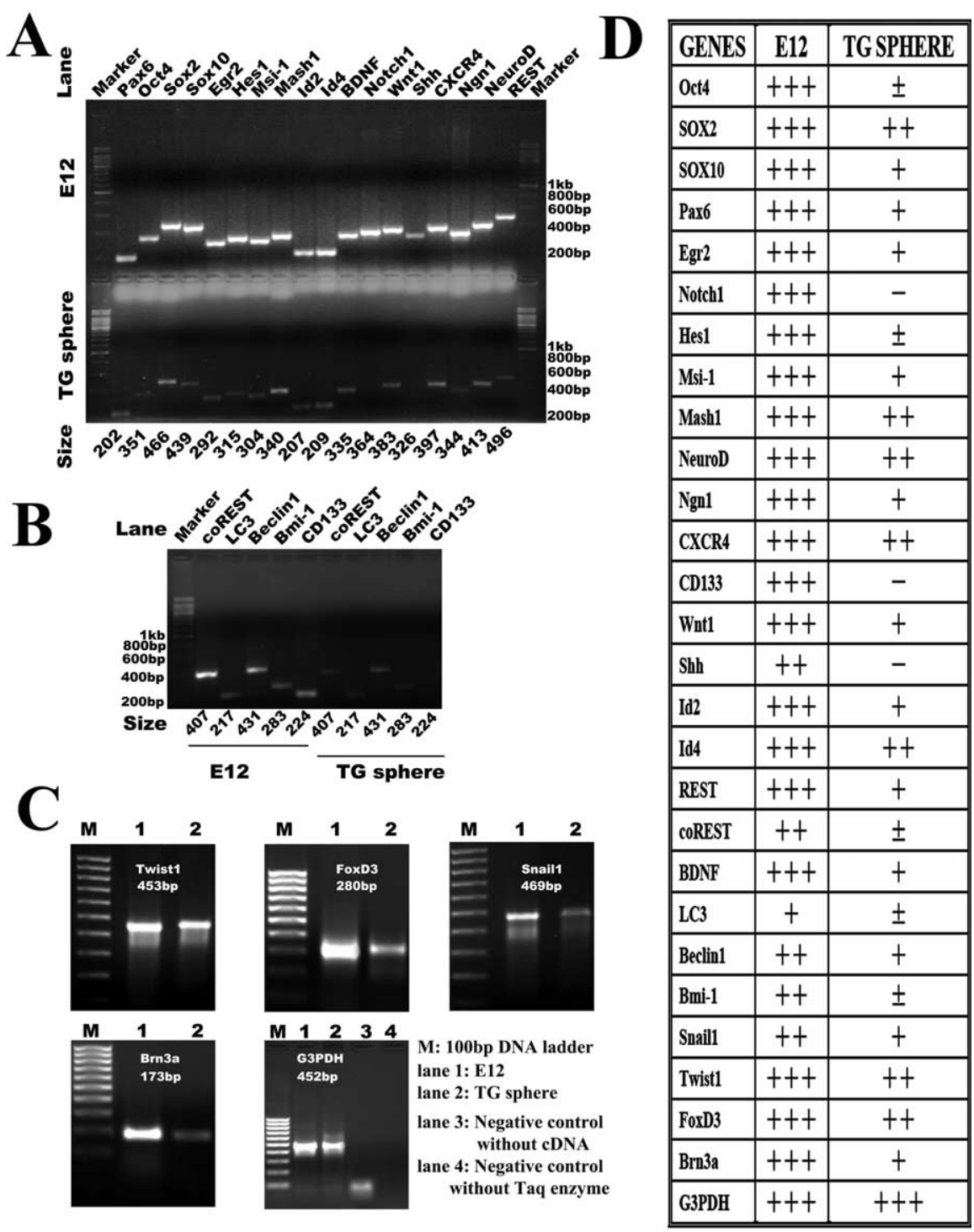

Figure 9. Molecular profile of adult TG-derived neurospheres. Gene expression profiles of TG-derived progenitor cells characterized by RT-PCR. Total RNA was isolated from adult TG-derived secondary spheres. Neurospheres express a set of markers of neural crest stem cell and also express distinct genes involved in proliferation, self-renewal, and self-clearing/autophagy. $\boldsymbol{A}-\boldsymbol{C}$ the result of the secondary spheres derived from adult TG. RT-PCR for G3PDH was used as a loading control. D, Tabularized results of RT-PCR for the tested genes in total RNA isolated from E12 rat tissue compared with adult TG-derived spheres: -, no signal; \pm , minor signal; + , weak signal; ++ , moderate signal; +++ , strong signal. Hes, Hairy and enhancer of split 1.

significant, loss of small neurons, resulting in an overall $20 \%$ loss. The counts of small neurons probably underestimate the actual loss of B-type cells, because any axotomized A-type cell becoming atrophic could likely be reclassified as B-type. Although no previous data are available for the chronically deafferented TG, our finding is consistent with studies on deafferented DRGs that used comparable methods, which show a $37 \%$ neuron loss, mainly affecting B-type cells, and a 50\% loss of unmyelinated axons (Coggeshall et al., 1997; Tandrup et al., 2000).

Origin and nature of the expanding neuron population in the adult TG

Because methodological shortcomings were unable to explain the increase in neuron number with age in TG, the first alternative was to look for delayed neurogenesis. Such explanation was already proposed for the appearance of "new neurons" in the DRG 
(Devor and Govrin-Lippmann, 1985; Devor et al., 1985), a suggestion that inspired studies using tritiated thymidine and BrdU (Ciaroni et al., 2000; Geuna et al., 2000). The results so far have been inconclusive because of the very low incidence of BrdU incorporation into neurons. Our findings with BrdU also are essentially negative, because we failed to find a single retrograde tracer-BrdU double-labeled neuron .

It was proposed that the new neurons in adult DRG could derive from differentiation of cells that at younger ages could not be recognized as neurons, and for that reason not be counted ( $\mathrm{St}$ Wecker and Farel, 1994; Meeker and Farel, 1997; Popken and Farel, 1997; Farel, 2002). These cells are characterized by being positive to neuronal markers, such as neurofilament, but are not traceable when HRP is applied to the periphery (Farel, 2003), suggesting that they had not yet extended their peripheral axons. Such cells were identified in the frog, in which the number of cells innervating the lower limb doubles with age, in proportion to the increase in body size (St Wecker and Farel, 1994; Meeker and Farel, 1997). However, no additional confirmation of the existence of these cells is found in recent literature, nor does similar data exist for the TG.

In this study, a population of $\mathrm{Nestin}^{+}$and $\mathrm{DCX}^{+}$cells was identified in the adult TG. Both markers have been related to neuronal maturation of neuronal precursors. Nestin has been found in cells present in neurogenic regions, in both glial and neuronal precursors. DCX has been closely related to neurogenesis, the migration of neuronal precursor cells, and the dendritic growth of newly generated neurons (Nacher et al., 2001; Brown et al., 2003; Rao and Shetty, 2004; Couillard-Despres et al., 2005; Koizumi et al., 2006; Plumpe et al., 2006), although its presence alone cannot be associated with neurogenesis (Nacher et al., 2001; Aigner et al., 2003). The presence of DCX in DRG or TG in vivo has not been studied previously, although it is known that DRG cells are not positive for DCX in vitro, nor can DCX be induced by lesioning the axon of these cells (Couillard-Despres et al., 2005). However, it is present in maturing cells in the first steps of neuronal commitment (McDonald and Wojtowicz, 2005) and has been found to coexist with Nestin in maturing neurons in the hippocampus, one of the recognized neurogenic regions (Steiner et al., 2006). The presence of DCX and Nestin labeling in the TG in cells resembling neurons but not positive for other markers of mature neurons could thus be related to some form of persistent maturation of neuronal precursors in the adult rat, which might be primarily responsible for the steady increase in the cell number in the first 8 months of age. This conclusion is further supported by the finding of precursor cells in the TG in vitro. We demonstrated here that there are cells in TG that are able to migrate, proliferate, and differentiate into various cell lineages in vitro. TG shares with DRG, at least in part, a common origin, because cells in both structures originate in the neural crest (D'Amico-Martel and Noden, 1983; Fontaine-Perus et al., 1985). Consistently, precursor cells found in our in vitro culture study have immunophenotypical features and express genes related to neural crest stem cells. Neural crest-derived structures seem to maintain a certain quantity of neural crest intermediate multipotent precursors until late in development, as is the case of DRG and peripheral nerves (Hagedorn et al., 1999; Morrison et al., 1999; Le Douarin and Dupin, 2003). In the fate determination steps of neural crest cells, intermediate precursors are present for both glial and neural cells. The differentiation to neural cells and specifically to sensory neurons seems to be determined by the expression of proneural genes such as Mash1 and Ngn1/2 (Anderson, 1999; Bertrand et al., 2002). Multipotent neural crest precursors have been isolated in neural crest derivatives in adults (Yoshida et al., 2006; Fernandes et al., 2007). Precursors have also been found recently in adult rat DRG, which have similar characteristics and gene expression profiles to those present in TG (Li et al., 2007). The cells we isolated in culture have a low proliferative potential, a fact that could be responsible for the lack of neuronal proliferation in the ganglion, but display neuronal differentiation capacity, as proven by the presence of $\mathrm{NF}_{200}{ }^{+}$and $\mathrm{DCX}^{+}$cells in the in vitro assays. These cells react in different ways to the presence of different trophic factors (data not shown), also related to ganglion cell differentiation and survival, and express proneural and proglial genes as well as genes related to their neural crest origin. Therefore, both our in vivo and in vitro findings support the idea that a possible pool of immature neuroglial neural crest precursor cells could be present in the adult TG and be responsible for the increase in sensory neurons found with age.

\section{Overview and future directions}

In this study, we demonstrated that the number of TG neurons increases with age in the adult male rat through the late differentiation of a pool of precursors present in the ganglion. This finding supports and extends previous studies in frog and rat DRGs (St Wecker and Farel, 1994; Meeker and Farel, 1997; Popken and Farel, 1997; Farel, 2002, 2003), which signaled differences between sensory ganglia and well defined neurogenic regions in CNS in which the birth of new neurons is the main strategy for the increase, or maintenance, of neuron numbers. Protracted differentiation could thus be a developmental strategy that confers an adaptive advantage to neural populations that need to respond to changes in their environment by adding or renewing neurons without the prerequisite of DNA synthesis or cell-cycle reentry. Neuronal addition in the periphery may significantly depend on target-derived signals, because this process is closely related to the increase in animal size and age. Future studies should therefore focus on further characterizing these precursors and finding their regulatory factors, as well as establishing their potential role in pathological conditions and use in reparative strategies.

\section{References}

Aigner L, Uyanik G, Couillard-Despres S, Ploetz S, Wolff G, MorrisRosendahl D, Martin P, Eckel U, Spranger S, Otte J, Woerle H, Holthausen H, Apheshiotis N, Fluegel D, Winkler J (2003) Somatic mosaicism and variable penetrance in doublecortin-associated migration disorders. Neurology 60:329-332.

Aldskogius H, Arvidsson J (1978) Nerve cell degeneration and death in the trigeminal ganglion of the adult rat following peripheral nerve transection. J Neurocytol 7:229-250.

Alexson TO, Hitoshi S, Coles BL, Bernstein A, van der Kooy D (2006) Notch signaling is required to maintain all neural stem cell populations-irrespective of spatial or temporal niche. Dev Neurosci 28:34-48.

Anderson DJ (1999) Lineages and transcription factors in the specification of vertebrate primary sensory neurons. Curr Opin Neurobiol 9:517-524.

Andres KH (1961) Untersuchungen den Feinbau von spinal Ganglien. Z Zellforsch Mikr Anat 55:1-48.

Androutsellis-Theotokis A, Leker RR, Soldner F, Hoeppner DJ, Ravin R, Poser SW, Rueger MA, Bae SK, Kittappa R, McKay RD (2006) Notch signalling regulates stem cell numbers in vitro and in vivo. Nature 442:823-826.

Avendaño C (2006) Stereology of neural connections. An overview. In: Neuroanatomical tract tracing: molecules, neurons, and systems (Záborszky L, Wouterlood FG, Lanciego JL, eds), pp 477-529. New York: Springer.

Avendaño C, Dykes RW (1996) Quantitative analysis of anatomical changes in the cuneate nucleus following forelimb denervation: a stereological morphometric study in adult cats. J Comp Neurol 370:491-500.

Avendaño C, Lagares A (1996) A stereological analysis of the numerical dis- 
tribution of neurons in dorsal root ganglia C4-T2 in adult macaque monkeys. Somatosens Mot Res 13:59-66.

Avendaño C, Machin R, Bermejo PE, Lagares A (2005) Neuron numbers in the sensory trigeminal nuclei of the rat: a GABA- and glycineimmunocytochemical and stereological analysis. J Comp Neurol 493:538-553.

Bao S, Wu Q, McLendon RE, Hao Y, Shi Q, Hjelmeland AB, Dewhirst MW, Bigner DD, Rich JN (2006) Glioma stem cells promote radioresistance by preferential activation of the DNA damage response. Nature 444:756-760.

Bermejo PE, Jimenez CE, Torres CV, Avendaño C (2003) Quantitative stereological evaluation of the gracile and cuneate nuclei and their projection neurons in the rat. J Comp Neurol 463:419-433.

Bertrand N, Castro DS, Guillemot F (2002) Proneural genes and the specification of neural cell types. Nat Rev Neurosci 3:517-530.

Biedenbach MA, Kalu DN, Herbert DC (1992) Effects of aging and food restriction on the trigeminal ganglion: a morphometric study. Mech Ageing Dev 65:111-125.

Brown JP, Couillard-Despres S, Cooper-Kuhn CM, Winkler J, Aigner L, Kuhn HG (2003) Transient expression of doublecortin during adult neurogenesis. J Comp Neurol 467:1-10.

Cecchini T, Cuppini R, Ciaroni S, Del Grande P (1993) Increased number of dorsal root ganglion neurons in vitamin-E-deficient rats. Somatosens Mot Res 10:433-443.

Cecchini T, Cuppini R, Ciaroni S, De Matteis R, Del Grande P (1994) Increased number of sciatic sensory neurons in vitamin-E-deficient rats. Somatosens Mot Res 11:269-278.

Cecchini T, Cuppini R, Ciaroni S, Barili P, De Matteis R, Del Grande P (1995) Changes in the number of primary sensory neurons in normal and vitamin-E-deficient rats during aging. Somatosens Mot Res $12: 317-327$

Cherkas PS, Huang TY, Pannicke T, Tal M, Reichenbach A, Hanani M (2004) The effects of axotomy on neurons and satellite glial cells in mouse trigeminal ganglion. Pain 110:290-298.

Chie E, Liu D, Zhou XF, Rush RA (2001) Quantification of neurotrophin mRNA by RT-PCR. Methods Mol Biol 169:81-90.

Ciaroni S, Cecchini T, Cuppini R, Ferri P, Ambrogini P, Bruno C, Del Grande $\mathrm{P}$ (2000) Are there proliferating neuronal precursors in adult rat dorsal root ganglia? Neurosci Lett 281:69-71.

Coggeshall RE (1991) Verification of the Devor et al. (1985) method of determining neural numbers. J Neurosci Methods 40:87-90.

Coggeshall RE, La Forte R, Klein CM (1990) Calibration of methods for determining numbers of dorsal root ganglion cells. J Neurosci Methods 35:187-194.

Coggeshall RE, Lekan HA, Doubell TP, Allchorne A, Woolf CJ (1997) Central changes in primary afferent fibers following peripheral nerve lesions. Neuroscience 77:1115-1122.

Couillard-Despres S, Winner B, Schaubeck S, Aigner R, Vroemen M, Weidner N, Bogdahn U, Winkler J, Kuhn HG, Aigner L (2005) Doublecortin expression levels in adult brain reflect neurogenesis. Eur J Neurosci 21:1-14

Cruz-Orive LM (1999) Precision of Cavalieri sections and slices with local errors. J Microsc 193:182-198.

D’Amico-Martel A, Noden DM (1983) Contributions of placodal and neural crest cells to avian cranial peripheral ganglia. Am J Anat 166:445-468.

Devor M, Govrin-Lippmann R (1985) Neurogenesis in adult rat dorsal root ganglia. Neurosci Lett 61:189-194.

Devor M, Govrin-Lippmann R (1991) Neurogenesis in adult rat dorsal root ganglia: on counting and the count. Somatosens Mot Res 8:9-12.

Devor M, Govrin-Lippmann R, Frank I, Raber P (1985) Proliferation of primary sensory neurons in adult rat dorsal root ganglion and the kinetics of retrograde cell loss after sciatic nerve section. Somatosens Res 3:139-167.

Dorph-Petersen KA, Nyengaard JR, Gundersen HJ (2001) Tissue shrinkage and unbiased stereological estimation of particle number and size. J Microsc 204:232-246.

Farel PB (2002) Sensory neuron addition in juvenile rat: time course and specificity. J Comp Neurol 449:158-165.

Farel PB (2003) Late differentiation contributes to the apparent increase in sensory neuron number in juvenile rat. Brain Res Dev Brain Res 144:91-98.

Fernandes KJ, Toma JG, Miller FD (2007) Multipotent skin-derived precur- sors: adult neural crest-related precursors with therapeutic potential. Philos Trans R Soc Lond B Biol Sci, in press.

Fontaine-Perus J, Chanconie M, Le Douarin NM (1985) Embryonic origin of substance $P$ containing neurons in cranial and spinal sensory ganglia of the avian embryo. Dev Biol 107:227-238.

Forbes DJ, Welt C (1981) Neurogenesis in the trigeminal ganglion of the albino rat: a quantitative autoradiographic study. J Comp Neurol 199:133-147.

Geuna S, Borrione P, Fornaro M, Giacobini-Robecchi MG (2000) Neurogenesis and stem cells in adult mammalian dorsal root ganglia. Anat Rec 261:139-140.

Greenwood AL, Turner EE, Anderson DJ (1999) Identification of dividing, determined sensory neuron precursors in the mammalian neural crest. Development 126:3545-3559.

Gundersen HJ, Bagger P, Bendtsen TF, Evans SM, Korbo L, Marcussen N, Moller A, Nielsen K, Nyengaard JR, Pakkenberg B (1988) The new stereological tools: disector, fractionator, nucleator and point sampled intercepts and their use in pathological research and diagnosis. APMIS 96:857-881.

Hagedorn L, Suter U, Sommer L (1999) P0 and PMP22 mark a multipotent neural crest-derived cell type that displays community effects in response to TGF-beta family factors. Development 126:3781-3794.

Hökfelt T, Zhang X, Wiesenfeld-Hallin Z (1994) Messenger plasticity in primary sensory neurons following axotomy and its functional implications. Trends Neurosci 17:22-30.

Kania G, Corbeil D, Fuchs J, Tarasov KV, Blyszczuk P, Huttner WB, Boheler KR, Wobus AM (2005) Somatic stem cell marker prominin-1/CD133 is expressed in embryonic stem cell-derived progenitors. Stem Cells 23:791-804.

Koizumi H, Higginbotham H, Poon T, Tanaka T, Brinkman BC, Gleeson JG (2006) Doublecortin maintains bipolar shape and nuclear translocation during migration in the adult forebrain. Nat Neurosci 9:779-786.

Kruger GM, Mosher JT, Bixby S, Joseph N, Iwashita T, Morrison SJ (2002) Neural crest stem cells persist in the adult gut but undergo changes in self-renewal, neuronal subtype potential, and factor responsiveness. Neuron 35:657-669.

Kuo LT, Simpson A, Schanzer A, Tse J, An SF, Scaravilli F, Groves MJ (2005) Effects of systemically administered NT-3 on sensory neuron loss and nestin expression following axotomy. J Comp Neurol 482:320-332.

La Forte RA, Melville S, Chung K, Coggeshall RE (1991) Absence of neurogenesis of adult rat dorsal root ganglion cells. Somatosens Mot Res 8:3-7. Lagares A, Avendaño C (2000) Lateral asymmetries in the trigeminal ganglion of the male rat. Brain Res 865:202-210.

Lai K, Kaspar BK, Gage FH, Schaffer DV (2003) Sonic hedgehog regulates adult neural progenitor proliferation in vitro and in vivo. Nat Neurosci 6:21-27.

Le Douarin NM, Dupin E (2003) Multipotentiality of the neural crest. Curr Opin Genet Dev 13:529-536.

Le Douarin NM, Creuzet S, Couly G, Dupin E (2004) Neural crest cell plasticity and its limits. Development 131:4637-4650.

Lee A, Kessler JD, Read TA, Kaiser C, Corbeil D, Huttner WB, Johnson JE, Wechsler-Reya RJ (2005) Isolation of neural stem cells from the postnatal cerebellum. Nat Neurosci 8:723-729.

Lendahl U, Zimmerman LB, McKay RD (1990) CNS stem cells express a new class of intermediate filament protein. Cell 60:585-595.

Li HY, Say EWM, Zhou XF (2007) Isolation and characterization of neural crest progenitors from adult dorsal root ganglia. Stem Cells, in press.

Lin Q, Lee YJ, Yun Z (2006) Differentiation arrest by hypoxia. J Biol Chem 281:30678-30683.

Ljungberg C, Novikov L, Kellerth JO, Ebendal T, Wiberg M (1999) The neurotrophins NGF and NT-3 reduce sensory neuronal loss in adult rat after peripheral nerve lesion. Neurosci Lett 262:29-32.

Lo L, Dormand E, Greenwood A, Anderson DJ (2002) Comparison of the generic neuronal differentiation and neuron subtype specification functions of mammalian achaete-scute and atonal homologs in cultured neural progenitor cells. Development 129:1553-1567.

Loh YH, Wu Q, Chew JL, Vega VB, Zhang W, Chen X, Bourque G, George J, Leong B, Liu J, Wong KY, Sung KW, Lee CW, Zhao XD, Chiu KP, Lipovich L, Kuznetsov VA, Robson P, Stanton LW, Wei CL, Ruan Y, Lim B, Ng $\mathrm{HH}$ (2006) The Oct4 and Nanog transcription network regulates pluripotency in mouse embryonic stem cells. Nat Genet 38:431-440.

Marzesco AM, Janich P, Wilsch-Brauninger M, Dubreuil V, Langenfeld K, 
Corbeil D, Huttner WB (2005) Release of extracellular membrane particles carrying the stem cell marker prominin-1 (CD133) from neural progenitors and other epithelial cells. J Cell Sci 118:2849-2858.

McDonald HY, Wojtowicz JM (2005) Dynamics of neurogenesis in the dentate gyrus of adult rats. Neurosci Lett 385:70-75.

McKay HA, Brannstrom T, Wiberg M, Terenghi G (2002) Primary sensory neurons and satellite cells after peripheral axotomy in the adult rat: timecourse of cell death and elimination. Exp Brain Res 142:308-318.

Meeker ML, Farel PB (1997) Neuron addition during growth of the postmetamorphic bullfrog: sensory neuron and axon number. J Comp Neurol 389:569-576.

Mohammed HA, Santer RM (2001) Total neuronal numbers of rat lumbosacral primary afferent neurons do not change with age. Neurosci Lett 304:149-152.

Molofsky AV, Pardal R, Iwashita T, Park IK, Clarke MF, Morrison SJ (2003) Bmi-1 dependence distinguishes neural stem cell self-renewal from progenitor proliferation. Nature 425:962-967.

Molofsky AV, He S, Bydon M, Morrison SJ, Pardal R (2005) Bmi-1 promotes neural stem cell self-renewal and neural development but not mouse growth and survival by repressing the p16Ink4a and p19Arf senescence pathways. Genes Dev 19:1432-1437.

Morrison SJ, White PM, Zock C, Anderson DJ (1999) Prospective identification, isolation by flow cytometry, and in vivo self-renewal of multipotent mammalian neural crest stem cells. Cell 96:737-749.

Morrison SJ, Csete M, Groves AK, Melega W, Wold B, Anderson DJ (2000) Culture in reduced levels of oxygen promotes clonogenic sympathoadrenal differentiation by isolated neural crest stem cells. J Neurosci 20:7370-7376.

Nacher J, Crespo C, McEwen BS (2001) Doublecortin expression in the adult rat telencephalon. Eur J Neurosci 14:629-644.

Nichols J, Zevnik B, Anastassiadis K, Niwa H, Klewe-Nebenius D, Chambers I, Scholer H, Smith A (1998) Formation of pluripotent stem cells in the mammalian embryo depends on the POU transcription factor Oct4. Cell 95:379-391.

Palma V, Lim DA, Dahmane N, Sanchez P, Brionne TC, Herzberg CD, Gitton Y, Carleton A, Alvarez-Buylla A, Altaba A (2005) Sonic hedgehog controls stem cell behavior in the postnatal and adult brain. Development 132:335-344.

Plumpe T, Ehninger D, Steiner B, Klempin F, Jessberger S, Brandt M, Romer B, Rodriguez GR, Kronenberg G, Kempermann G (2006) Variability of doublecortin-associated dendrite maturation in adult hippocampal neurogenesis is independent of the regulation of precursor cell proliferation. BMC Neurosci 7:77.

Popken GJ, Farel PB (1997) Sensory neuron number in neonatal and adult rats estimated by means of stereologic and profile-based methods. J Comp Neurol 386:8-15.

Rao MS, Shetty AK (2004) Efficacy of doublecortin as a marker to analyse the absolute number and dendritic growth of newly generated neurons in the adult dentate gyrus. Eur J Neurosci 19:234-246.

Rogers ML, Atmosukarto I, Berhanu DA, Matusica D, Macardle P, Rush RA (2006) Functional monoclonal antibodies to p75 neurotrophin receptor raised in knockout mice. J Neurosci Methods 158:109-120.
Steiner B, Klempin F, Wang L, Kott M, Kettenmann H, Kempermann G (2006) Type-2 cells as link between glial and neuronal lineage in adult hippocampal neurogenesis. Glia 54:805-814.

Stemple DL, Anderson DJ (1992) Isolation of a stem cell for neurons and glia from the mammalian neural crest. Cell 71:973-985.

Studer L, Csete M, Lee SH, Kabbani N, Walikonis J, Wold B, McKay R (2000) Enhanced proliferation, survival, and dopaminergic differentiation of CNS precursors in lowered oxygen. J Neurosci 20:7377-7383.

St Wecker PGR, Farel PB (1994) Hindlimb sensory neuron number increases with body size. J Comp Neurol 342:430-438.

Tandrup T (1993) A method for unbiased and efficient estimation of number and mean volume of specified neuron subtypes in rat dorsal root ganglion. J Comp Neurol 329:269-276.

Tandrup T, Gundersen HJ, Jensen EB (1997) The optical rotator. J Microsc 186:108-120.

Tandrup T, Woolf CJ, Coggeshall RE (2000) Delayed loss of small dorsal root ganglion cells after transection of the rat sciatic nerve. J Comp Neurol 422:172-180.

Tucker RP (2004) Neural crest cells: a model for invasive behavior. Int J Biochem Cell Biol 36:173-177.

Vega JA, Rodriguez C, Medina M, del Valle ME (1990) Neuron-specific enolase (NSE)-like and neurofilament protein (NFP)-like immunoreactivities in the rat dorsal root ganglia and sciatic nerve. Cell Mol Biol 36:537-546.

Wachs FP, Couillard-Despres S, Engelhardt M, Wilhelm D, Ploetz S, Vroemen M, Kaesbauer J, Uyanik G, Klucken J, Karl C, Tebbing J, Svendsen C, Weidner N, Kuhn HG, Winkler J, Aigner L (2003) High efficacy of clonal growth and expansion of adult neural stem cells. Lab Invest 83:949-962.

West MJ (1993) New stereological methods for counting neurons. Neurobiol Aging 14:275-285.

West MJ (1999) Stereological methods for estimating the total number of neurons and synapses: issues of precision and bias. Trends Neurosci 22:51-61.

West MJ, Slomianka L, Gundersen HJ (1991) Unbiased stereological estimation of the total number of neurons in thesubdivisions of the rat hippocampus using the optical fractionator. Anat Rec 231:482-497.

Ygge J, Aldskogius H, Grant G (1981) Asymmetries and symmetries in the number of thoracic dorsal root ganglion cells. J Comp Neurol 202:365-372.

Yoon K, Gaiano N (2005) Notch signaling in the mammalian central nervous system: insights from mouse mutants. Nat Neurosci 8:709-715.

Yoshida S, Shimmura S, Nagoshi N, Fukuda K, Matsuzaki Y, Okano H, Tsubota K (2006) Isolation of multipotent neural crest-derived stem cells from the adult mouse cornea. Stem Cells 24:2714-2722.

Zhou XF, Rush RA, McLachlan EM (1996) Differential expression of the p75 nerve growth factor receptor in glia and neurons of the rat dorsal root ganglia after peripheral nerve transection. J Neurosci 16:2901-2911.

Zhou XF, Li WP, Zhou FH, Zhong JH, Mi JX, Wu LL, Xian CJ (2005) Differential effects of endogenous brain-derived neurotrophic factor on the survival of axotomized sensory neurons in dorsal root ganglia: a possible role for the p75 neurotrophin receptor. Neuroscience 132:591-603. 